\title{
AS LUCERNAS ROMANAS DO MONTE MOLIÃO (LAGOS, PORTUGAL) ROMAN LAMPS FROM MONTE MOLIÃO, (LAGOS, PORTUGAL)
}

\author{
CARLOS PEREIRA* \\ ANA MARGARIDA ARRUDA*
}

\begin{abstract}
"La science lychnologique, à l'instar de la céramologie, de la numismatique, de l'archéo-botanique ou de la paléo-trichologie, reste indissociable de l'archéologie: à partir de vestiges matériels, aussi modestes soientils, il convient essentiellement de saisir l'homme dans sa complexité et sa relation avec l'univers. Dans cette quête, longue et difficile, parfois désespérée, il importe d'améliorer sans cesse les outils de détermination et d'interprétation, de veiller à la multiplicité et à la diversité des approches, qu'il s'agisse d'analyses de laboratoire, d'études typologiques, chrono-quantitatives, technologiques, iconographiques ou économiques, sans oublier les dimensions culturelles et anthropologiques et tout en restant à l'écoute d'autres spécialistes."
\end{abstract}

Daniel Paunier AA.VV., Nouveautés Lychnologiques. Suisse, Lychnoservices (2003) 5.

Resumo: O trabalho de campo que vem sendo desenvolvido no sítio arqueológico de Monte Molião, Lagos, Portugal, tem permitido a recolha de um considerável conjunto de lucernas romanas republicanas e alto-imperiais. Dá-se, agora, a conhecer a totalidade do conjunto, que denuncia uma inesperada preponderância de exemplares da série de volutas, mas também alguns exemplares de produção genuinamente hispânica, como é o caso dos tipos Riotinto-Aljustrel ou Andújar. As dinâmicas comerciais reflectidas pelas lucernas não são, apesar de tudo, surpreendentes, se considerarmos que o sítio gozou de relativa importância durante o final do século I d.C. e o início da centúria seguinte. Apresenta-se, pela primeira vez, um faseamento preliminar da ocupação romana para Monte Molião, legitimada pela necessidade de integrar contextualmente alguns artefactos.

Palavras-chave: lucernas romanas; comércio; iconografia; fabrico.

* UNIARQ (Centro de Arqueologia. Universidade de Lisboa). Faculdade de Letras. 1600-214. Lisboa. Portugal. Correo-e: a.m.arruda@ letras.ulisboa.pt, carlos_samuel_pereira@hotmail.com
Abstract: The archaeological work carried out in Monte Molião, Lagos, Portugal, allowed collecting a considerable number of Republican and High Imperial Roman lamps. The set exhibit an unexpected preponderance of volute series, but also some Hispanic examples, such as Tinto-Aljustrel types or Andújar. The trade dynamics reflected by the lamps are not surprising, considering that the site enjoyed a relative importance during the late I century and the beginning of the II. The presentation of a preliminary phasing of Roman occupation of Monte Molião is legitimized by the need to integrate some artefacts.

Key Words: Roman lamps; trade; iconography; clays. 


\section{INTRODUÇÃO}

As recentes intervenções arqueológicas realizadas em Monte Molião, Lagos (fig. 1), realizadas no âmbito do Projecto de Investigação "Monte Molião na Antiguidade" e efectuadas ao abrigo de um protocolo existente entre a Câmara Municipal de Lagos e a Faculdade de Letras da Universidade de Lisboa, permitiram a recolha de um considerável volume de informação sobre a sua ocupação humana, materializada quer em estruturas quer em artefactos. Entre estes últimos, encontramos as lucernas romanas, de que este trabalho se ocupa.

$\mathrm{O}$ estudo do conjunto revela-se importante, não apenas pelos materiais em si, já bem conhecidos do ponto de vista tipológico e com balizas cronológicas bem estabelecidas, mas principalmente porque contribui para o acerto da cronologia do faseamento ocupacional do sítio algarvio. Por outro lado, é importante recordar que, sendo as lucernas artefactos particularmente bem estudados, a sua recuperação em contextos conservados é muito rara em áreas habitacionais, como é o caso agora em estudo.

A escassez de lucernas da série de disco em Monte Molião e a abundância das de volutas chamou desde o início a nossa atenção, até porque o momento de transição entre ambas está centrado na passagem do século I d.C. para o II, ou na(s) primeira(s) décadas(s) do último. Assim sendo, a carência de lucernas de disco não parecia compatível com outros dados do sítio algarvio, que esteve ocupado, pelo menos, até ao início do último quartel do século II (Viegas e Arruda 2013; 2014), situação que implicaria a existência de um número considerável de lucernas de tipo Dressel-Lamboglia 20 e mesmo 27/28. Contudo, deve também dizer-se que a elevada quantidade de lucernas de volutas não causa qualquer estranheza, atendendo à densa ocupação do sítio a partir do terceiro quartel do século I d.C., o que parece concordar com o momento em que esta série estava em claro auge de consumo, concretamente a época flávia e os inícios da antonina.

$\mathrm{O}$ conjunto lacobrigense permitiu ainda constatar que o tipo genuinamente hispânico Riotinto-Aljustrel chegou em número considerável a esta área da província da Lusitânia, o que, concordando com os restantes materiais importados, corrobora que o sul desta província parecia estar mais conectado, no que à actividade comercial diz respeito, com a província da Bética, ainda que administrativamente estivesse integrada naquela.

Pouco comuns nas áreas meridionais são as lucernas de canal. Esta forma já havia sido identificada em Ossonoba, Faro (Pereira 2012a) e Balsa, Torre d’Ares
(Pereira 2014b: 121). Podemos agora afirmar que está também presente em Lagos, Laccobriga?, preenchendo os três principais núcleos que se supõe terem tido alguma importância político-administrativa na actual região algarvia, ainda que o Monte Molião não apresente a mesma visibilidade arqueológica (Arruda 2007; Arruda e Pereira 2010; Arruda et al. 2010).

Importa ainda referir que este estudo não pretende ser inovador na metodologia da abordagem. Limitamo-nos, assim, a seguir as tradicionais linhas de investigação de estudo das lucernas romanas.

O trabalho que efectuámos teve, como é evidente, em consideração o sítio propriamente dito, nomeadamente o faseamento da sua ocupação e a sua cronologia, construída com base na análise destes e de outros materiais e na sua localização na sequência estratigráfica observada. Ainda assim, o contributo das lucernas para a afinação das datações propostas para cada uma das fases foi importante, mesmo admitindo que, em alguns casos, esse contributo não tenha sido particularmente relevante. De qualquer modo, a divulgação, junto da comunidade científica, de um conjunto numeroso de lucernas romanas parece por si só justificar-se, até porque não é frequente a recuperação deste tipo de materiais em contextos urbanos conservados.

A análise das pastas das lucernas seguiu os critérios aplicados pela maioria dos investigadores que se dedica ao estudo destes materiais, critérios que foram também utilizados, descritos e matizados por um de nós no estudo sobre as lucernas da Alcáçova de Santarém (Pereira 2014: 10-15). O estudo e descrição das pastas, concretamente a identificação e caracterização dos elementos não plásticos, foram efectuados macroscopicamente, tendo incidido sobre a totalidade do conjunto. As descrições foram feitas com base em: tipo de argila; natureza; forma e frequência de elementos não plásticos; textura; dureza; cor; engobe/verniz e sua tonalidade e cozedura. Estes critérios foram os propostos por Stienstra (1986) e têm sido ampliados e ajustados por estudos mais recentes (p. e. Morillo Cerdán 1999).

A análise física das pastas das lucernas é um processo que ganha cada vez mais importância no estudo destes materiais, mas, infelizmente, a maioria não tem correspondência com o respectivo centro produtor, uma vez que nem todos estes últimos estão devidamente reconhecidos. Ainda assim, foi possível, em alguns casos, propor a região ou área de fabrico, através da análise comparativa com outros materiais que seguramente aí foram produzidos. Estas associações de determinadas pastas a regiões concretas são naturalmente meras propostas de trabalho, uma vez que, e tal como Ángel 


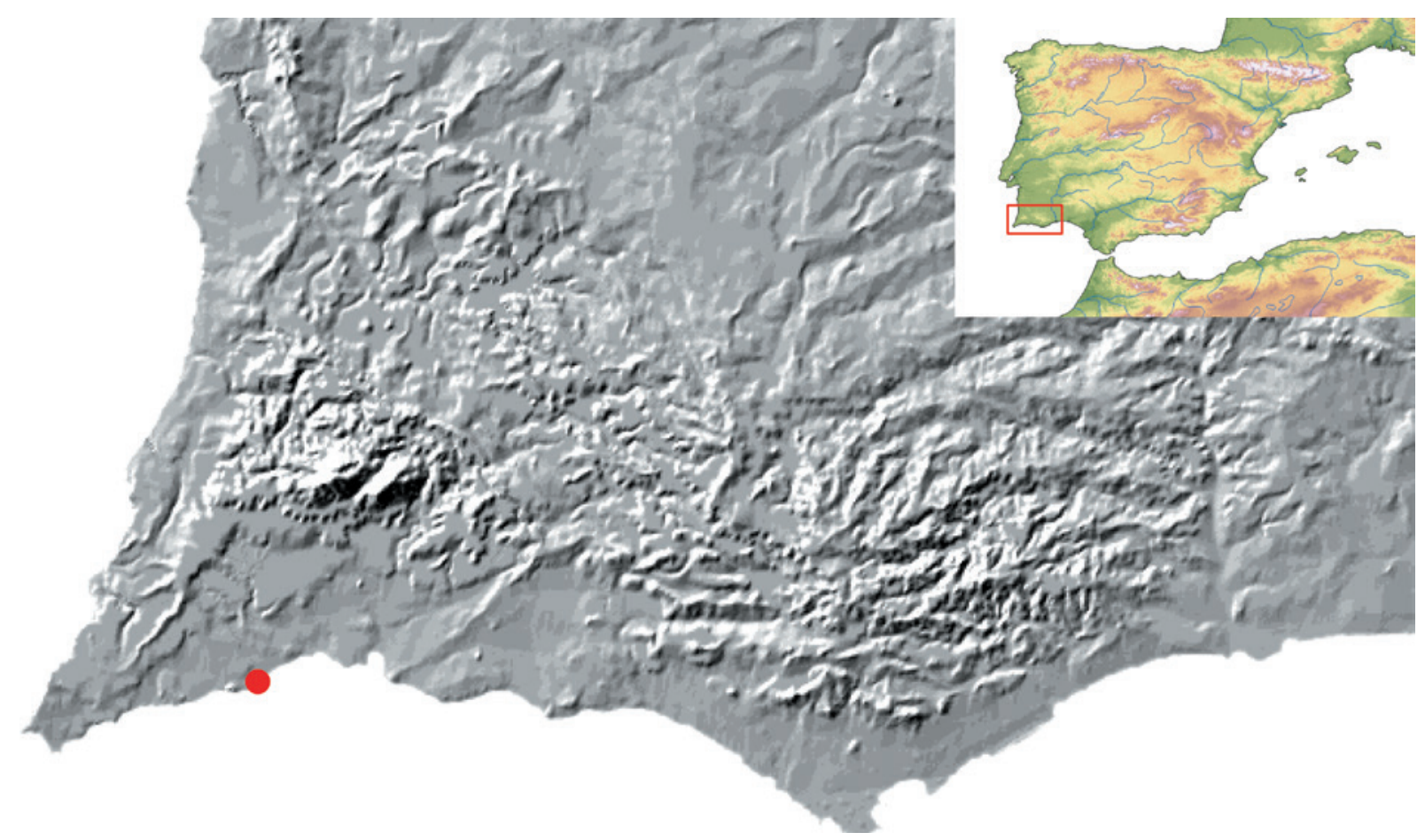

Figura 1. Localização do Monte Molião, Lagos, Portugal.

Morillo Cerdán lembrou, apenas uma elaborada análise química e física de pastas, efectuada nos diferentes sítios arqueológicos, bem como a concretização de uma base de dados internacional, poderiam resolver a questão (1999: 278).

O trabalho que agora se publica tem, pois, por objectivos fundamentais a divulgação de um conjunto lychnológico inédito e a apresentação preliminar do faseamento ocupacional romano imperial de Monte Molião.

\section{O SÍTIO E A SUA EVOLUÇÃO EM ÉPOCA ROMANA}

Ainda que a bibliografia sobre Monte Molião seja já bastante abundante (entre outros: Arruda 2007; Arruda et al. 2008; Arruda e Pereira 2010; Arruda et al. 2010; Dias 2010; Lourenço 2010; Arruda e Sousa 2012), é imprescindível apesentar aqui alguns dados sobre o faseamento da sua ocupação humana, de forma a contextualizar, devidamente, o conjunto das lucernas nos diferentes sectores escavados no sítio (fig. 2).

Localizado na margem esquerda da foz da ribeira de Bensafrim, no concelho de Lagos, a colina que hoje se conhece por Monte Molião foi ocupada desde a Idade do Ferro. A proximidade a recursos marinhos, a terras férteis e a outros recursos naturais, como poderá ser o caso dos minérios ou da caça (Detry e Arruda 2013), justificará em grande parte a preferência. Refira-se, ainda, que a implantação topográfica do sítio lhe assegurava alguma defensabilidade e ampla visibilidade.

A sequência da ocupação é já relativamente bem conhecida (Arruda et al. 2008). A sua génese vem sendo atribuída ao século IV a.C. (Ibid.: 188; Arruda et al. 2011), materializando-se em uma ocupação pré-romana bastante bem documentada na arquitectura e, também, nos materiais exumados. Mas ainda que a construção da maioria das estruturas seja atribuída a esse século, concretamente à sua segunda metade, parece ter sido durante o seguinte que Monte Molião gozou de um maior poder aquisitivo (Ibid.).

O século II a.C. é, contudo, bem mais complexo de avaliar. Os primeiros vestígios de uma ocupação romana, quer no que se refere a contextos quer ao nível dos materiais, parecem ser tardios dentro dessa baliza temporal (Arruda e Sousa 2012: 129), e os pré-romanos não permitem ser prolongados até momentos avançados desse século. A ocupação romana republicana parece ter sido iniciada nos finais do terceiro quartel do século II, ocupação que, no entanto, delata diferentes ritmos de importação. 


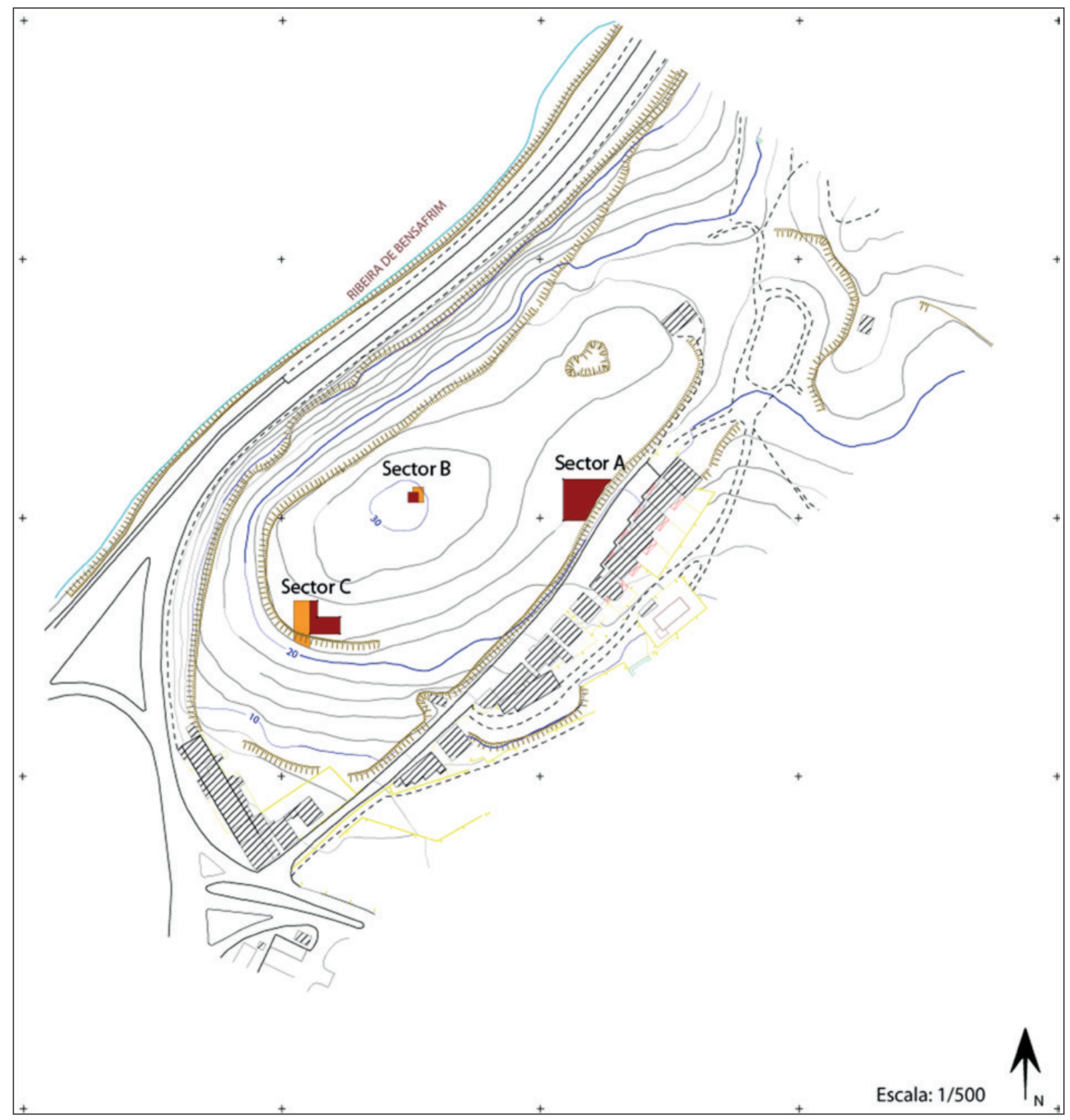

Figura 2. Localização das diferentes áreas intervencionadas (sectores) no Monte Molião, Lagos.

Tendo em consideração os vestígios arqueológicos encontrados, Monte Molião deverá corresponder a Laccobriga, núcleo urbano referido por Pompónio Mela e por Plutarco, relacionando-se com o episódio das guerras sertorianas relatado pelo último autor (Sertorius, XIII, 4-6). Com efeito, os contextos que foi possível escavar indiciam uma ocupação bastante densa entre o início do último quartel do século II a.C. e as duas primeiras décadas da centúria seguinte (Arruda e Sousa 2012: 129-130), ocupação que parece retrair-se a partir de então. Naturalmente que há dados que comprovam que o sítio não foi abandonado por completo, nomeadamente alguns escassos materiais da segunda metade do século I a.C., que surgiram descontextualizados, e portanto não associados a quaisquer estruturas construídas. Assim, e independentemente da questão de Laccobriga 
e da sua associação a Monte Molião, a verdade é que após as duas primeiras décadas do século I a.C. o sítio perdeu parte importante do seu poder aquisitivo, facto que poderá estar relacionado com uma crise económica ou demográfica, mas que contrasta com o observado em outros núcleos habitacionais coevos da região algarvia (Arruda et al. 2006; Sousa 2009; 2010; Viegas 2006; 2011). Em qualquer caso, a realidade observada em Monte Molião após o final das guerras sertorianas poderá ter relação com o facto de ter sido apoiante do exército lusitano (Arruda e Sousa 2012: 130).

Refira-se, contudo, que outras explicações já foram ensaiadas, como é o caso de uma possível ocorrência de sismo (Gomes 2010: 15, 20, 76 e ss.), provavelmente seguido de tsunami (Arruda e Sousa 2012: 130; Detry e Arruda 2013). Porém, outros sítios que sofreram os mesmos fenómenos não transparecem uma quebra económica e demográfica tão abrupta, nem tão prolongada no tempo (Silva et al. 2005).

Esta situação, indiciada pela ausência de construções e/ou reconstruções ao nível da arquitectura e pela pouca expressividade de produtos importados, manteve-se até meados do século I d.C., altura em que o sítio voltou a destacar-se como um dos mais dinâmicos do Algarve. Todavia, o estado actual da investigação evidencia que nunca viria a gozar de equipamentos públicos equivalentes aos das principais cidades romanas, nem a ter a mesma visibilidade que Ossonoba ou Balsa, o que obriga a considerar um papel menos importante nas actividades político-administrativas no quadro da ocupação romana (Pereira 2012b: 176). Porém, é de destacar a construção de estruturas que parecem obedecer a um plano arquitectural prévio, e que correspondem a espaços habitacionais divididos em várias células, organizados em função de arruamentos. Esta renovação urbanística de meados do século I d.C. está acompanhada por um notável desenvolvimento da actividade comercial, consubstanciada em numerosas importações, de produtos alimentares (envasados em ânforas) e manufacturados (cerâmica comum e de mesa), com origem, fundamentalmente, na província da Bética (ânforas e cerâmica comum), como, aliás, é frequente nos sítios do Algarve.

Em momento centrado na segunda metade do século II, Monte Molião é abandonado (Arruda et al. 2008: 189; Arruda et al. 2010: 301). Mas parece muito provável que a população que aí estava instalada se tenha deslocado para a margem oposta da ribeira de Bensafrim, onde se vinha fixando desde, pelo menos, meados do século anterior. Ainda assim, é indispensável lembrar que a sua necrópole continuou a ser utilizada até ao século III, muito provavelmente pelos agora instalados na margem oposta (Arruda et al. 2010; Pereira 2014b: 391-392).

Por outro lado, em 2011, foi possível detectar uma ocupação residual do final do século IV/início do V, que corresponde, contudo, a um episódio sem antecedentes directos que não reflecte uma reocupação efectiva da colina.

\subsection{Fases ocupacionais}

Embora tenhamos já exposto, em linhas muito gerais, a evolução da ocupação do Monte Molião e algumas das suas problemáticas, importa efectuar ainda uma descrição breve das diferentes fases dentro do período romano. Este exercício torna-se necessário uma vez que durante o tratamento do conjunto lychnológico (sobre o conceito Videm Pereira e Albuquerque 2014: 15 , nota 32 ) far-se-á referência às fases em que se inserem os seus contextos de recolha. Os momentos (fases) em que dividimos a ocupação romana de Monte Molião têm, em alguns casos, balizas cronológicas bastante precisas, deixando evidenciada a dinâmica em que cada um deles se insere (construção, remodelação, retracção, abandono). Saliente-se, ainda, que estas informações serão relevantes para a leitura final de uma categoria de materiais que, raras vezes, aparece em contextos conservados, em áreas habitacionais.

A ocupação republicana de Monte Molião pôde ser dividida em duas fases ocupacionais distintas (Arruda e Pereira 2010: 698-699; Arruda e Sousa 2012), sendo a mais recente divisível em subfases. Foram documentadas, sobretudo, em um dos sectores intervencionados $(C)$ e não estão integralmente plasmadas nos restantes (A e B).

A mais antiga caracteriza-se pela construção e utilização dos primeiros edifícios romanos (fig. 3). Associados a estas estruturas detectaram-se os níveis mais antigos e recolheram-se materiais cronologicamente integráveis no último quartel do século II a.C. (ânforas de tipo Dressel 1A itálicas, Mañá C2 gaditanas e norte africanas, cerâmica campaniense predominantemente de tipo A, cerâmica de tipo Kuass, cerâmica de paredes finas do tipo II de Mayet).

Os edifícios desta fase, que não evidenciam uma absoluta simetria, não sofreram grandes remodelações ou acrescentos durante a sua utilização, mas somente uma intensa sucessão de estratos de ocupação, no seu interior.

A que se lhe seguiu caracteriza-se por uma alteração da malha urbana (fig. 4), que é agora mais organizada e planificada. As estruturas prévias foram, contudo, 


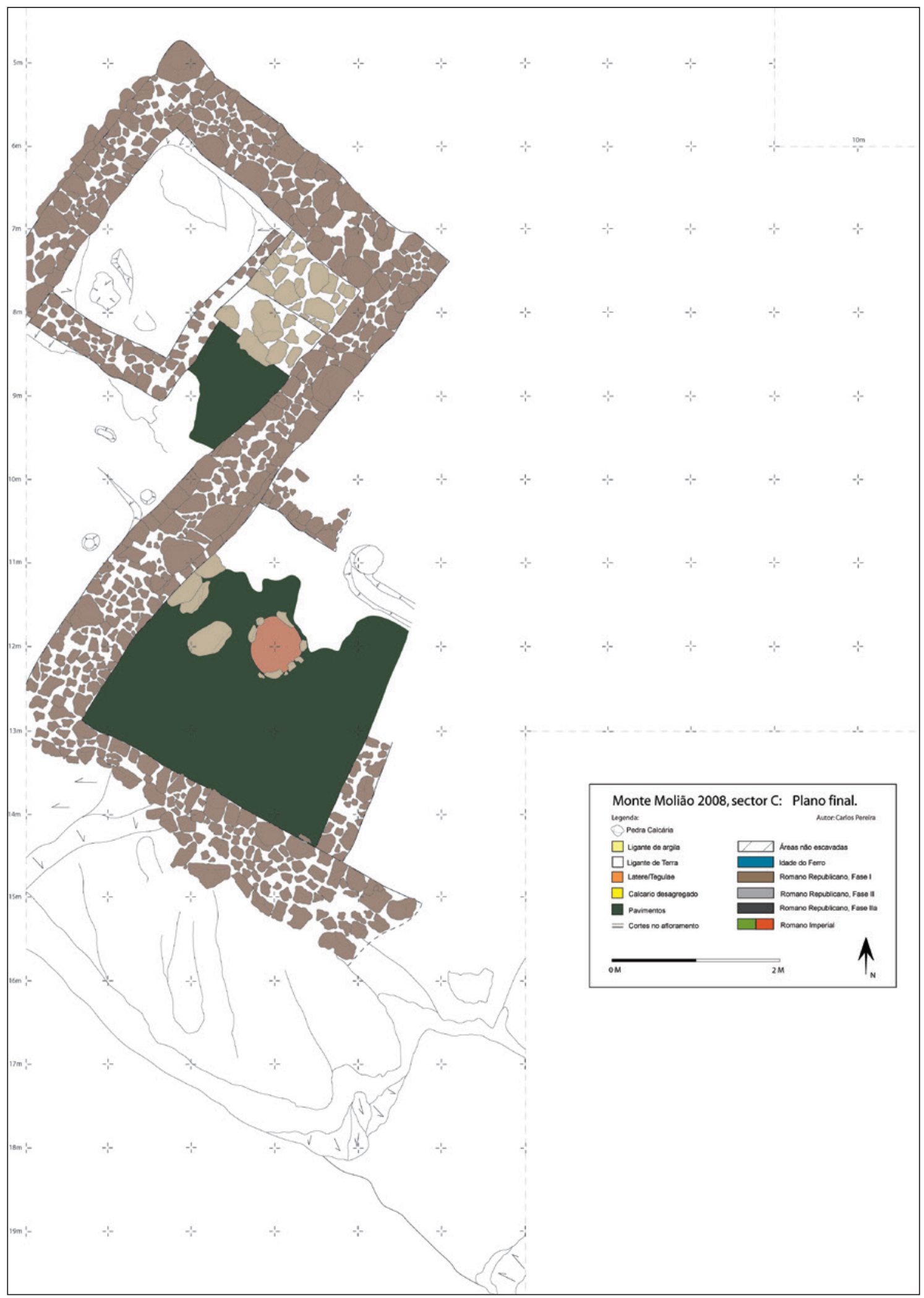

Figura 3. Planta das estruturas da fase romana-republicana mais antiga, sector C. 


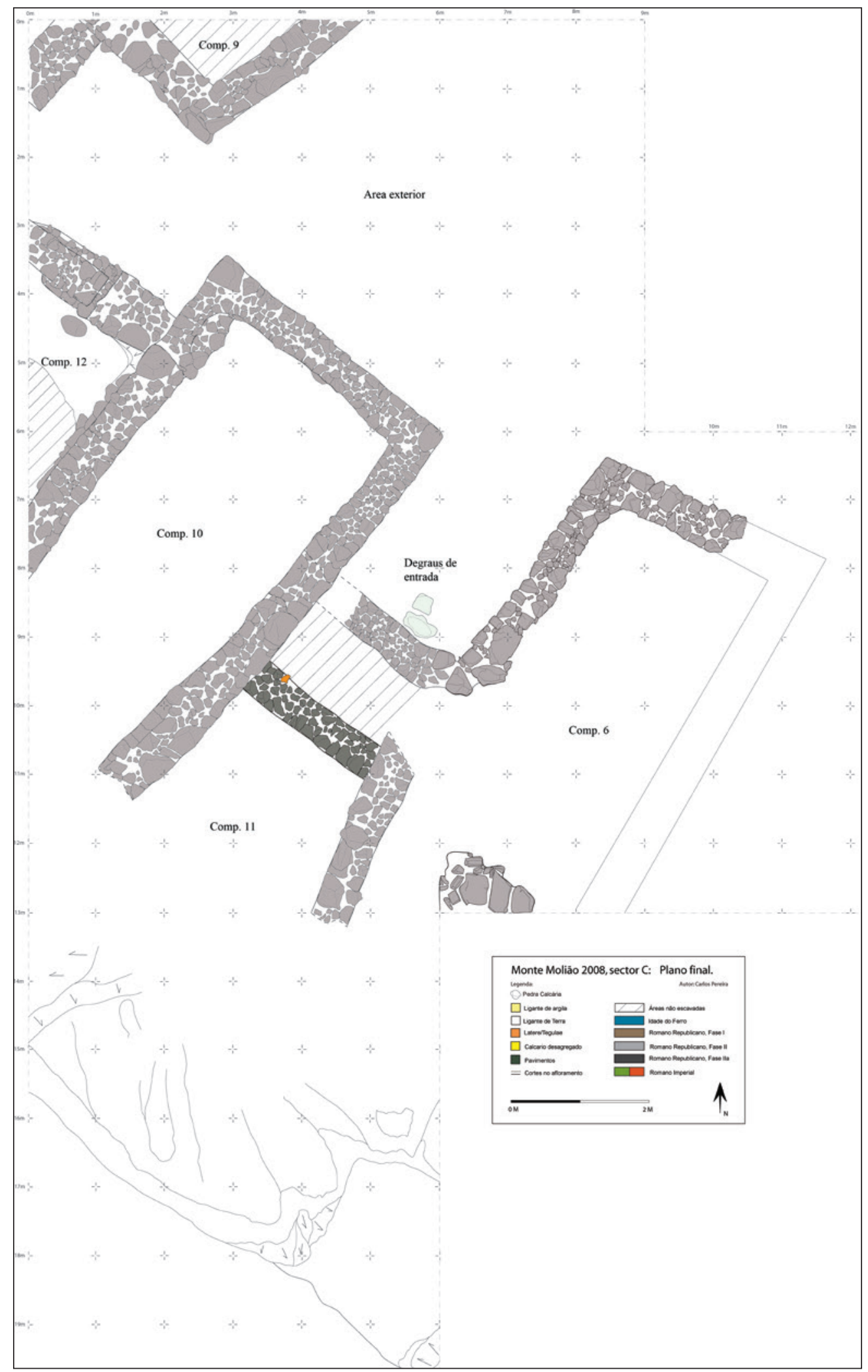

Figura 4. Planta das estruturas da fase romana-republicana mais recente, sector C. 


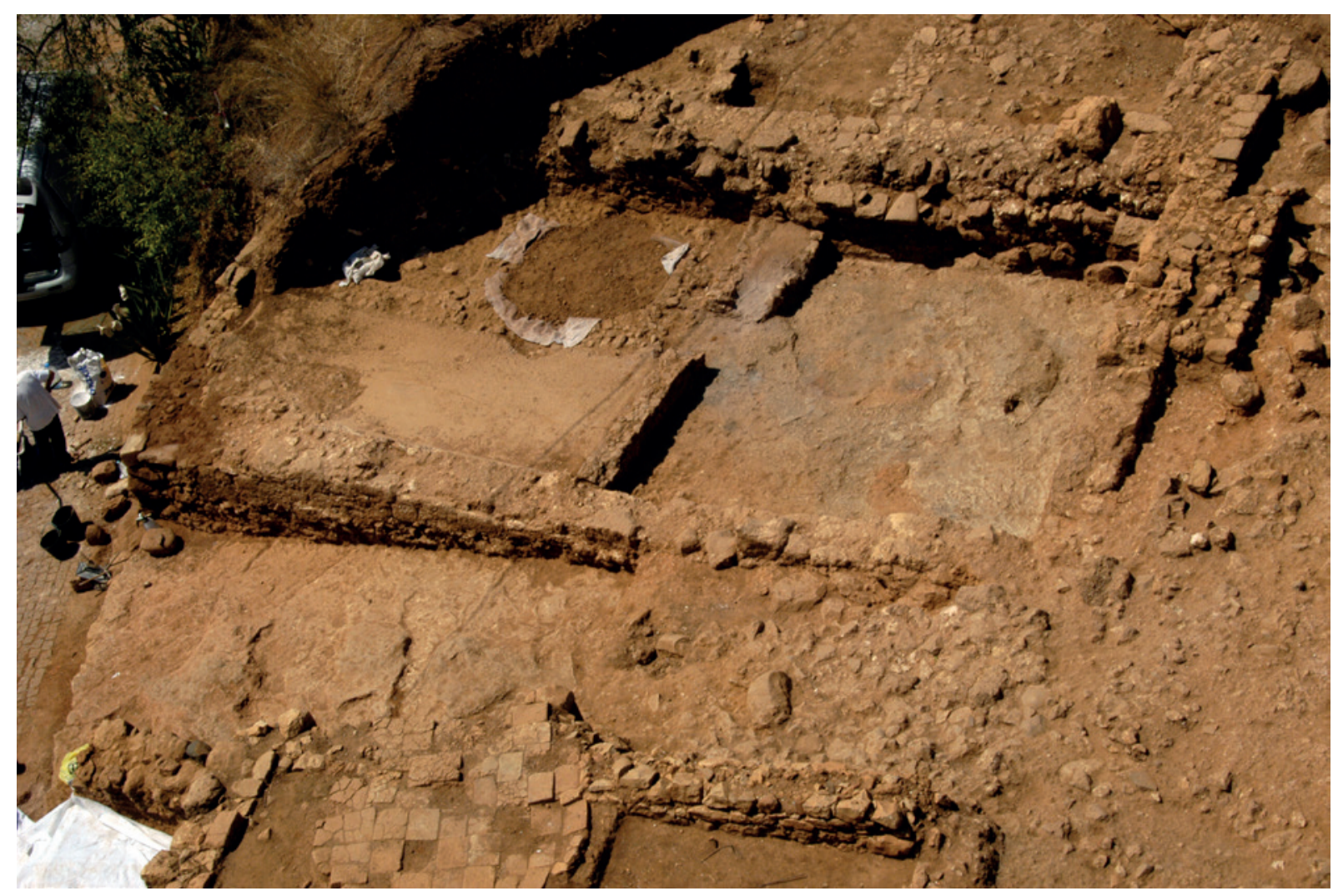

Figura 5. Fotografia dos compartimentos 5 e 6 pertencentes à fase mais antiga, detectada até ao momento, da ocupação romana imperial.

reaproveitadas, tendo sido a partir delas que se desenvolveram os novos edifícios. A cota de utilização foi sobrelevada e, durante esta fase, ao contrário da anterior, os pavimentos parecem ter sido sucessivamente reparados/ utilizados, realidade que justificará a menor potência estratigráfica. A planta dos edifícios de um dos sectores (C) parece estar organizada em torno de uma área exterior que dava acesso a, pelo menos, dois edifícios.

Cronologicamente, parece aceitável, para os níveis desta fase, uma baliza que abarque o primeiro quartel do século I a.C., ainda associados a ânforas de tipo Dressel 1 itálicas, mas com um aumento significativo das Mañá C2 e Castro Marim 1 gaditanas (Arruda e Sousa 2012: 129). A cerâmica de paredes finas engloba as formas 3 e 8 de Mayet, mantendo-se também a cerâmica campaniense de tipo $\mathrm{A}$, aumentando numericamente a originária de Cales (Arruda e Pereira 2012: 698; Dias 2010).

Parece desnecessário repetir todo o fenómeno que ocorreu após este momento. Relembramos, contudo, que o sítio terá permanecido ocupado, a julgar pelo aparecimento pontual de materiais posteriores, do final da república e do início do império, que, até ao momento, não apareceram associados a quaisquer construções. Esta situação ter-se-á mantido até, sensivelmente, ao início da $2^{\mathrm{a}}$ metade do século I d.C., momento em que a povoação começou a ganhar uma renovada dinâmica.

Também a ocupação romana imperial é susceptível de ser dividida em distintas fases, materializadas em um conjunto de construções de considerável dimensão e leitura. A mais antiga, localizada no sector A, ofereceu contextos datáveis da segunda metade do século I d.C. (Viegas e Arruda 2013: 729-730), concretamente em dois compartimentos de um edifício (os 5 e 6, fig. 5), tendo em um deles sido identificadas duas cetariae, de pequena dimensão, cuja produção se destinaria a um consumo de âmbito doméstico (Ibid.). O acesso a estes tanques era efectuado por uma plataforma linear que estava ligada a um compartimento anexo, destinado ao armazenamento dos produtos piscícolas aí transformados. Esta interpretação foi possível devido ao aparecimento de uma apreciável quantidade de contentores de armazenamento, 


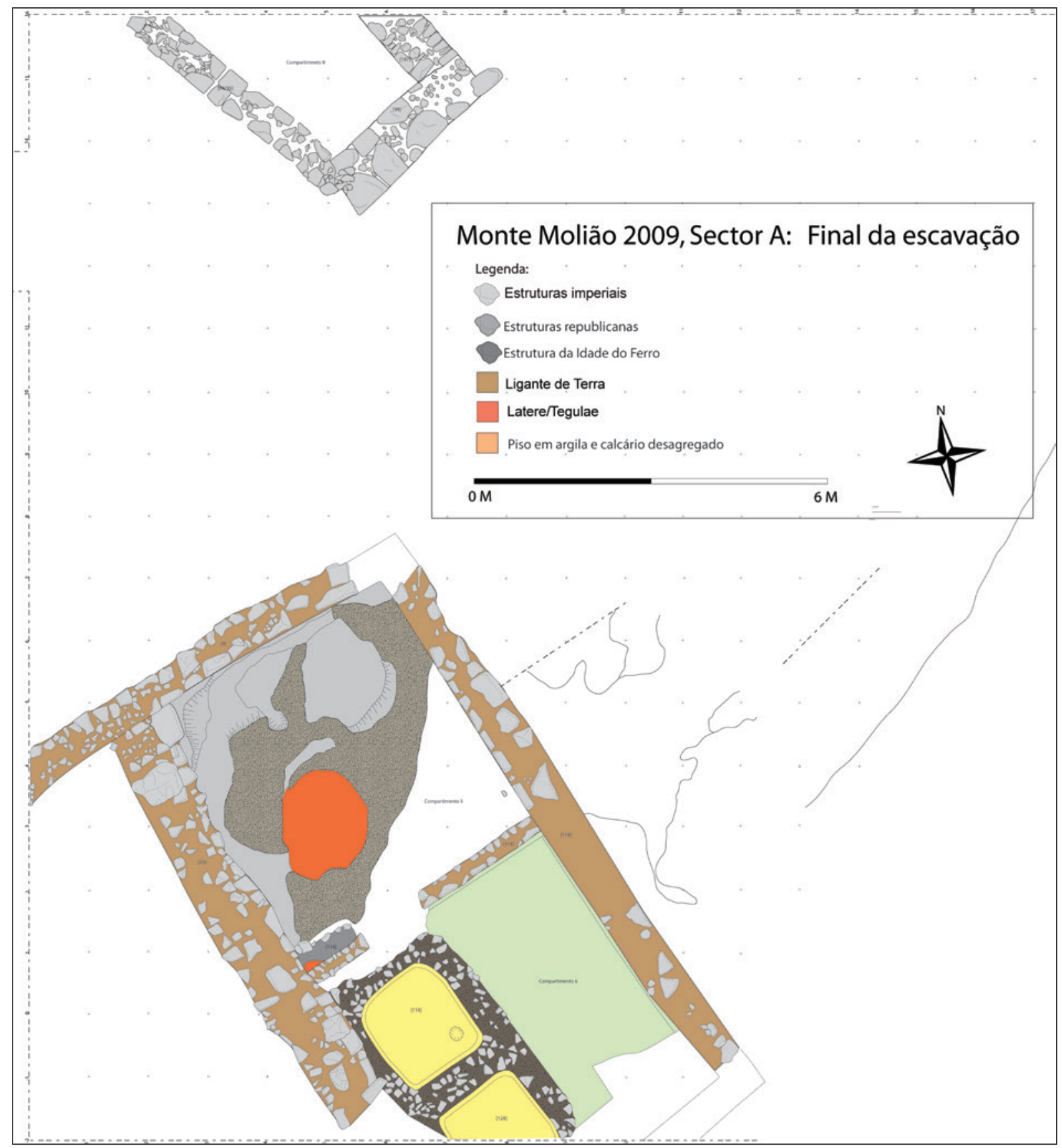

Figura 6. Planta das estruturas da fase romana imperial mais antiga, detectada no sector A.

concretamente dolia e ânforas oleárias reaproveitadas (Viegas e Arruda 2013), que ainda continham restos de fauna ictiológica.

Tal como aconteceu na fase mais antiga do período republicano, o abandono destes compartimentos terá sido repentino. Ambos estavam sepultados sob densos e espessos níveis de derrube das paredes e da cobertura, o que, aliás, possibilitou a sua conservação, não sendo ainda claros os motivos que levaram à sua inutilização.

A esta fase construtiva (fig. 6) pudemos associar ainda parte do edifício que se desenvolvia a Oeste, concretamente o Compartimento 8, não sendo impossível pensar que o edifício que existe a Sul poderá ter ainda origem nesta época. Contudo, a grande maioria 


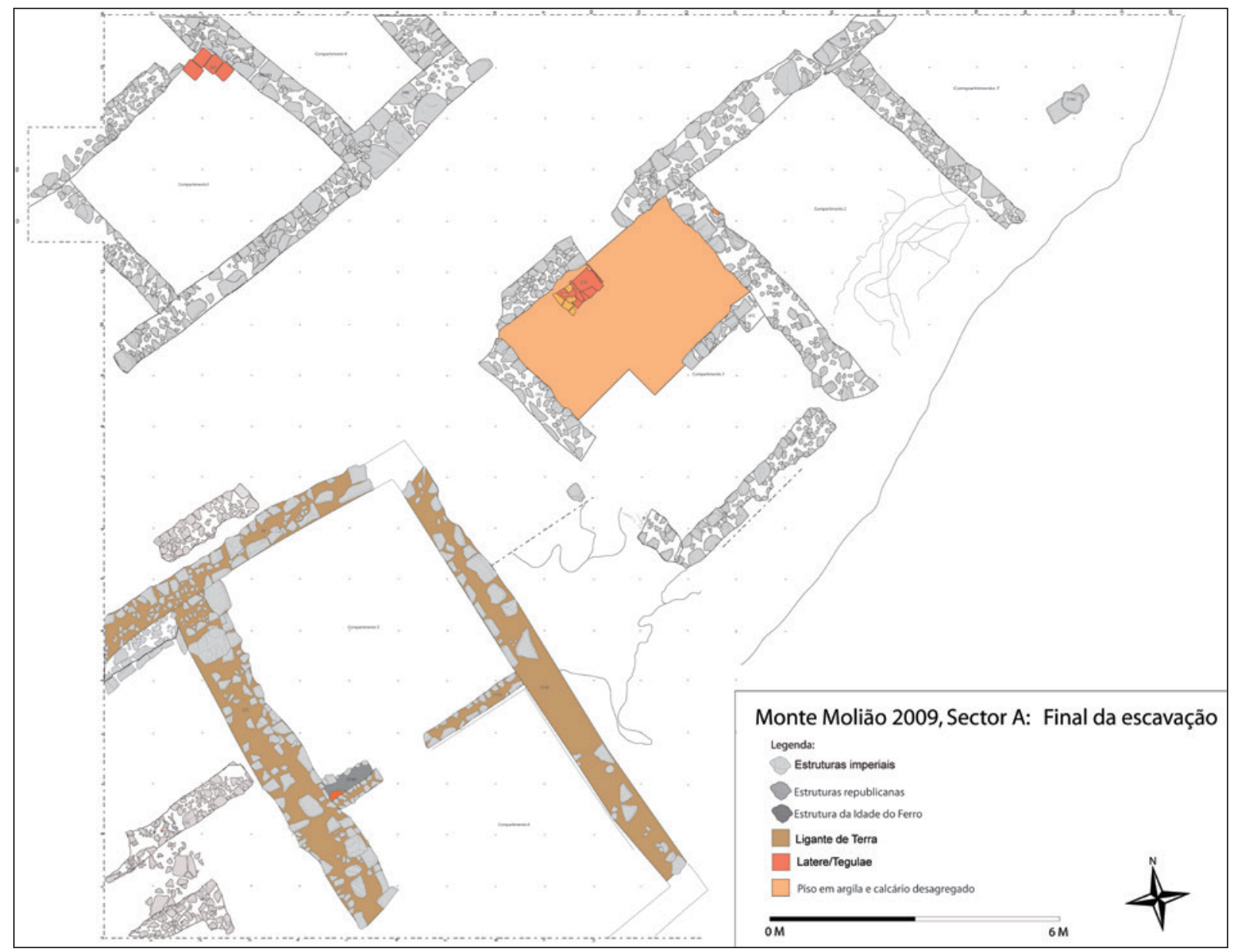

Figura 7. Planta das estruturas da $2^{\mathrm{a}}$ fase romana imperial, detectada no sector $\mathrm{A}$.

da informação que deste último pudemos extrair data de um momento mais tardio, já do século II.

Não é fácil datar, com precisão, o momento em que ocorreu o planeamento e a construção das edificações que se sobrepuseram à $1^{\text {a }}$ fase (fig. 7), mas parece aceitável que tenha ocorrido ainda durante os últimos decénios do século I d.C. Trata-se de um conjunto urbano que engloba três estruturas de carácter habitacional divididas em várias células, algumas com origem na fase anterior, e que estão separadas por arruamentos (Arruda et al. 2008; 2010; Viegas e Arruda 2013).

Contemporâneos deverão ser os fornos escavados no sector $\mathrm{C}$, destinados ao fabrico de cerâmica comum, que foram datados entre final do século I d.C. e a segunda metade do seguinte (Arruda et al. 2010: 301).

Finalmente, a fase mais tardia, identificada principalmente no sector $A$, protagonizou a decadência e abandono do local enquanto principal aglomerado populacional da região, ainda que admitamos a sua episódica frequência (Viegas e Arruda 2013: 730). Esta, talvez por ser a que se encontrava mais à superfície e portanto mais afectada por trabalhos agrícolas, é de mais difícil interpretação. Caracteriza-se por uma degradação generalizada das estruturas já existentes e pela construção de poucas outras, nas quais se utilizou, sobretudo, materiais perecíveis, que não deixaram vestígios claros da sua existência. Ainda que se tenham documentado alguns restos de paredes construídas em alvenaria, também se registaram outras técnicas na delimitação de espaços que usaram restos cerâmicos. A madeira e a taipa podem também ter sido utilizadas.

Atendendo à escassez de níveis e estruturas desta fase, não é fácil avançar uma datação. Ainda assim, parece aceitável que tenha ocorrido em momento centrado da segunda metade do século II d.C. 
Não podemos deixar de recordar que a evolução urbanística apresentada, e o respectivo faseamento, têm por base dados recuperados numa ínfima parte da área do povoado e que outras poderão fornecer, no futuro, dados que esclareçam os hiatos e as continuidades.

\section{O CONTIBUTO DAS LUCERNAS}

O conjunto de lucernas romanas recolhidas, até ao momento, neste sítio arqueológico conta com um total de 214 fragmentos distribuíveis entre lucernas tardo-republicanas (sete exemplares) e as séries imperiais de volutas (83 exemplares), de canal (dois exemplares) e de disco (três exemplares), sendo os restantes, infelizmente, de série indeterminada (118 exemplares). Identificou-se ainda a asa de um exemplar "bilychnis", que pode corresponder quer a uma peça da série de volutas quer da de disco (fig. 8).

A exposição seguiu esta ordem, e, dentro de cada série, foram apresentadas as formas segundo a tipologia de Dressel (1899), posteriormente actualizada e melhorada por Nino Lamboglia (1952). Quando as pastas o permitiram, foi avançada a origem de cada uma das peças e discutido o seu contexto de recolha, com o objectivo de verificar se as cronologias da categoria e da forma coincidem. A iconografia e a epigrafia foram analisadas separadamente.

\subsection{Morfologia e cronologia}

\subsubsection{Lucernas tardo-republicanas}

Ainda que a colina do Monte Molião conserve abundantes contextos romano-republicanos, que ofereceram um considerável número de materiais arqueológicos, apenas se reconheceram sete lucernas deste período, das quais apenas uma foi recolhida em um contexto primário de deposição (fig. 9).

Quatro deles correspondem a bicos (fig. 9 e 10), que apresentam características que permitem a sua inclusão no tipo 3 estabelecido por Dressel, revisto, posteriormente, por Marina Ricci (1973: 193-197). Trata-se de peças robustas, com duas aletas laterais espessas, em que o bico é, geralmente, longo e com as extremidades alargadas (Pereira 2008: 58-59). Os exemplares incluídos neste tipo são sempre lisos, não contendo qualquer decoração no disco ou nas orlas, ao contrário da forma precedente, que apresenta óvulos em relevo na orla. $\mathrm{O}$ disco, plano e liso, é geralmente delimitado por uma ou duas molduras bem marcadas, que o separam do corpo da lucerna.

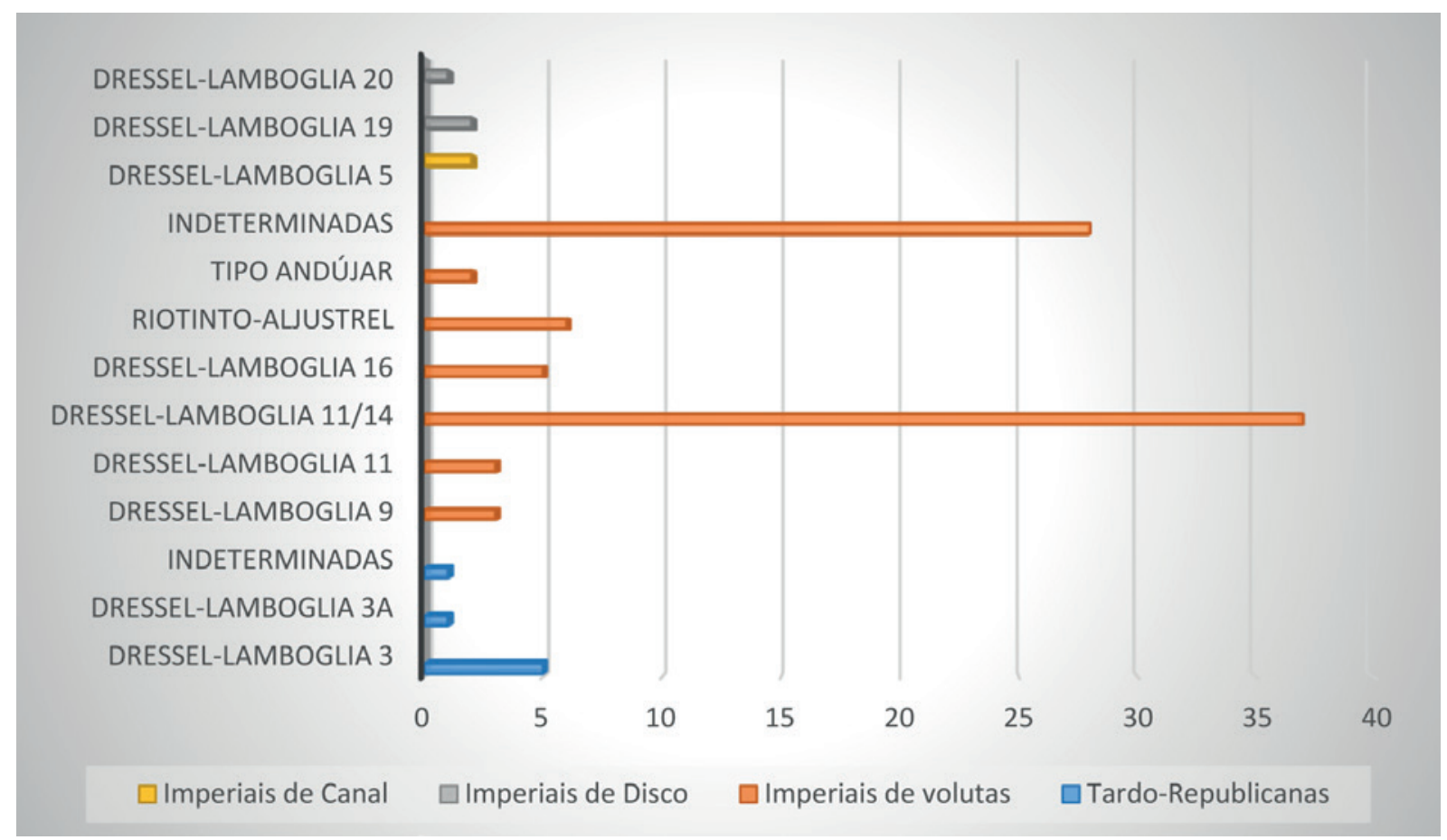

Figura 8. Distribuição morfológica das lucernas romanas do sítio. 


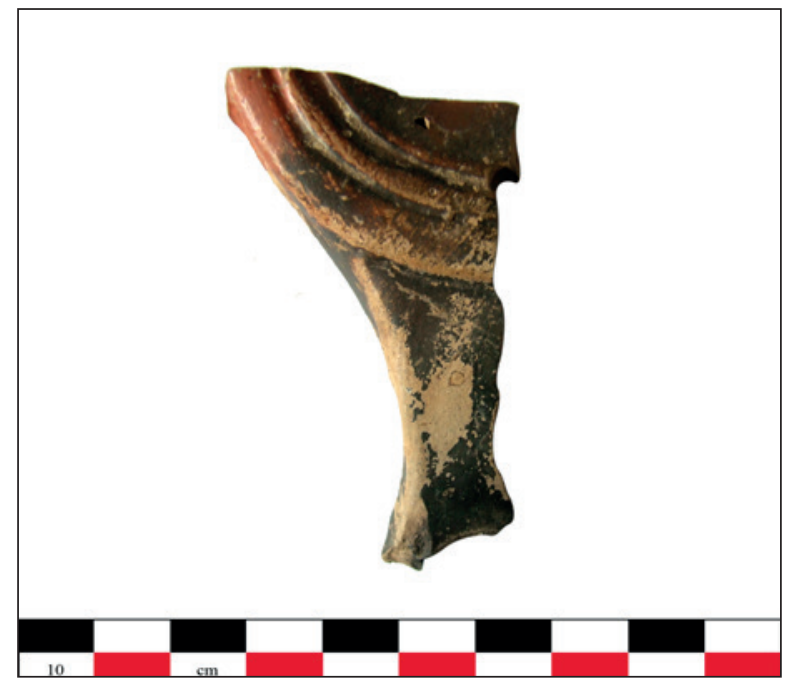

Figura 9. Fragmento de lucerna do tipo Dressel-Ricci 3.

Apesar da sua classificação, os exemplares lacobrigenses apresentam características próprias que os distinguem dos seus protótipos. Do ponto de vista morfológico, a principal diferença reside no comprimento do bico, maior em alguns casos algarvios. No entanto, ostentam as extremidades alargadas, molduras a separar o bico do disco e, principalmente, uma destacável ausência de decoração. Esta última característica permite, à partida, a sua exclusão em formas anteriores. Porém, as maiores diferenças entre estes fragmentos estão nas características tecno-petrográficas, que, na nossa opinião, denunciam diferentes origens. Sublinhamos, todavia, que o estado actual sobre o conhecimento das pastas desta categoria não permite, ainda, avançar propostas seguras.

Um dos maiores problemas na análise das pastas das lucernas romanas-republicanas é a grande variedade de argilas que foi utilizada na sua produção, situação que foi também observada em Monte Molião, onde nenhum dos três exemplares se assemelha. Um dos bicos (fig. 9) tem pasta de tonalidade acastanhada, muito compacta, homogénea e dura. É muito depurada, contendo muito poucos e pequenos desengordurantes difíceis de identificar. $\mathrm{O}$ engobe é fino, mas muito aderente, pouco homogéneo e de tonalidade que varia entre o laranja escuro e o negro. Parece evidente que não estamos perante uma peça que tenha sido fabricada na área meridional da Península Ibérica. As pastas dessa região são sempre muito polvorentas e, no caso das lucernas, nunca conservam o engobe/verniz ou apenas oferecem ténues vestígios dele, como é o caso de dois dos exemplares (fig. $10, \mathrm{n}^{\circ} 1$ e fig. 11). Não será descabido intuir que se trata, o bico referido antes, de uma importação itálica, a qual terá acompanhado as ânforas Dressel 1 (Arruda e Sousa 2012) e a cerâmica campaniense (Dias 2010), artefactos que foram abundantemente consumidos neste aglomerado urbano. Além disso, a pasta coincide com as descrições da autora italiana (Ricci 1973: 195).

Outro bico (fig. 10, $\mathrm{n}^{\mathrm{o}}$ 1), morfologicamente idêntico, oferece, por sua vez, uma pasta de tonalidade bege acinzentada, compacta, homogénea e muito polvorenta. É muito depurada, contendo poucos e pequenos desengordurantes difíceis de identificar e não tem qualquer vestígio de engobe. Como já referimos, estas características apontam para um fabrico do Sul peninsular, situação que, a julgar pelo volume de materiais originários da área de Cádis, não estranhamos.

Não é fácil o estudo tecno-petrográfico desta categoria de lucernas. A grande variedade de argilas contrasta, pelo menos no caso dos sítios algarvios, com a dos exemplares imperiais, nos quais se nota uma evidente homogeneidade, quer na origem quer nas características. Claro que o estabelecimento de poucas, mas marcantes, figlinae na Hispânia, durante o Alto-Império, foram determinantes para a existência deste contraste.

Durante o período republicano a situação era bem distinta e o escasso volume de materiais, que, geralmente, é recolhido, obriga a ter em consideração a própria definição de comércio lychnológico, motivo pelo qual muitos autores associam o consumo de lucernas a estabelecimentos militares (Romero Carnicero 1990: 287; Nunes et al. 1990: 85; Morillo Cerdán 1999: 333-334). Quando os materiais são de um acampamento militar, como por exemplo Cáceres el Viejo (Ulbert 1984), as lucernas serão de produção local/regional, mas podem ter sido fabricadas por artífices romanos, que acompanharam os contingentes militares. Para exemplares itálicos recolhidos em sítios de habitat, como é o caso em análise, a situação altera-se, não parecendo descabido pensar que terão pertencido a agentes itálicos que se fixaram na Península Ibérica, ou mesmo a indivíduos "romanizados", que aderiram aos hábitos romanos (Pereira 2008: 40). Mais difícil de justificar é, contudo, a presença, nos mesmos sítios de habitat, de materiais dos mesmos tipos, mas com pastas hispânicas. Voltaremos a este assunto mais adiante.

Atendendo às características de um dos exemplares, e à sua suposta origem, não é improvável que a área de Cádis se tivesse assumido como produtora pioneira destes materiais, ainda que nunca viessem a ter a mesma visibilidade que os seus congéneres itálicos.

A cronologia que vem sendo acolhida para esta forma abarca todo o século I a.C., ainda que em alguns 


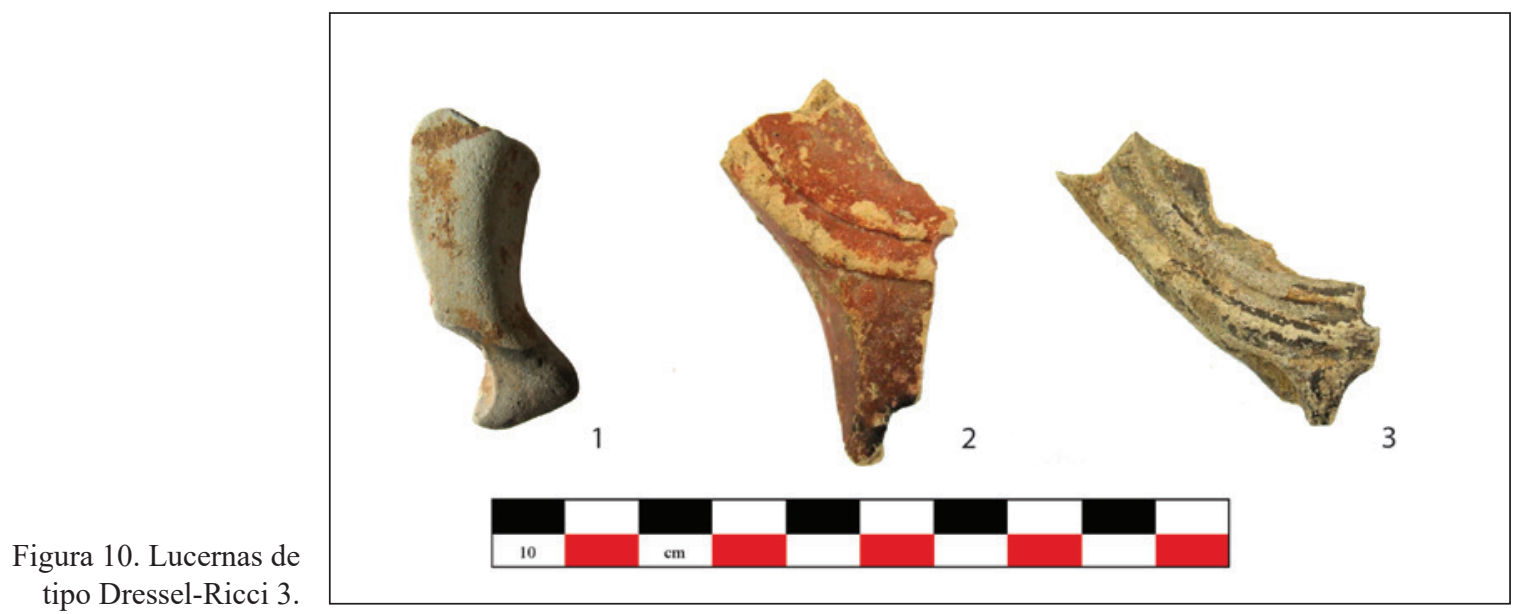

sítios tenha sido datada de momento anterior (Bémont e Lahanier 1985: 236-238). No naufrágio de Madrague de Giens e Fos 2, foram datadas do segundo quartel do século I a.C., no de Titan de 50 a.C. e no de Valle Ponti foi-lhe atribuída uma datação centrada em torno à viragem da Era (Ricci 2002: 337-347). Refira-se ainda a sua identificação no acampamento militar da Lomba do Canho (Nunes et al. 1990: 78) e na Alcáçova de Santarém (Pereira 2008: 59) também em contextos de meados/segunda metade do século I a.C.

Infelizmente, a maioria dos exemplares de Monte Molião foi recolhida em estratos imperiais (sector A e Cisterna), não estando, portanto, em contexto primário de deposição. Mas um dos bicos é proveniente de um nível escavado em um dos compartimentos do edifício identificado no sector $\mathrm{C}$, que pudemos relacionar com o momento final da ocupação da fase mais antiga deste período (final do século II/início do século I a.C.). Efectivamente, o nível estratigráfico onde apareceu a lucerna correspondia a uma camada de lixeira, que deve estar relacionada com a destruição/ remodelação do edifício. Lembre-se, neste contexto que Ricci admitiu que a produção desta forma ter-se-á iniciado ainda no final do século II a.C. (1973: 197), surgindo mais tarde os exemplares com o disco decorado (Dressel-Ricci 3A) e com volutas estilizadas a ladear o bico. Parece, portanto aceitável uma cronologia centrada no final do século II e início do I a.C. quer para a forma em geral, quer para o exemplar de Monte Molião.

Outro fragmento (fig. 11) desta série é uma aleta integrável na mesma forma (3), mais concretamente na variante A individualizada pela investigadora italiana (Ricci 1973: 199), que tem como principal diferença a existência de volutas estilizadas entre o bico e

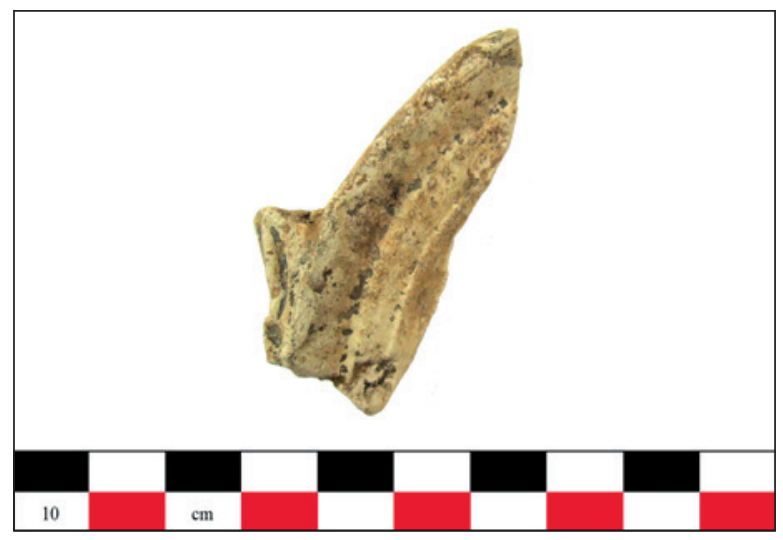

Figura 11. Fragmento de lucerna do tipo Dressel-Ricci 3A.

o disco (Ibid.; Pereira 2014a: 24), característica que viria a marcar a série imperial. Esta variante do tipo 3 foi, de facto, bastante inovadora do ponto de vista morfológico, motivo pelo qual Marina Ricci a individualizou, não sendo descabido considerar que foi com este tipo que se iniciaram as alterações formais que vieram a dar origem à série seguinte (Ricci 1973: 200).

Os exemplares de Albintimilium, que a autora apresentou no seu trabalho, oferecem cronologias inseridas entre os anos 90-30 a.C. Todavia, os dados obtidos em naufrágios, como são os casos de Madrague de Giens ou de Fos 2 (Ricci 2002), permitiram obter datações maioritariamente do segundo quartel ou mesmo meados do século I a.C.

Este fragmento foi recolhido em um estrato de enchimento da cisterna, de construção republicana, que abasteceu a colina durante largo tempo. Todavia, não podemos associar esta peça a esta estrutura hidráulica, justificado pelo facto de os estratos de enchimento/ 
inutilização serem mais tardios, ainda que as cerâmicas embutidas nas argamassas de construção delatem uma construção antiga.

\subsubsection{Lucernas imperiais de volutas}

As lucernas imperiais da série de volutas são as mais abundantes do conjunto, representando 38,8\% da totalidade, percentagem ultrapassada apenas pelos fragmentos indeterminados. Como já referimos na Introdução, esta elevada presença de lucernas de volutas não deixa de impressionar, uma vez que a ocupação do sítio se prolonga até ao final do terceiro quartel do século II d.C. Contudo, os níveis do século I d.C. são particularmente ricos em importações, o que pode justificar, em grande medida, esta situação.

Em Monte Molião foram recolhidos três fragmentos de bico pertencentes ao tipo 9 de Dressel-Lamboglia (fig. 12), um em contexto de revolvimento e dois recolhidos nos níveis de enchimento da cisterna, localizada no topo da colina. A forma é característica da $1^{\mathrm{a}}$ metade do século I d.C., mas a variante $\mathrm{C}$ pode alcançar a segunda ou mesmo o início do século seguinte (Bisi 1977: 81). Ainda assim, lembramos que a ausência de construções e contextos claramente júlio-cláudios não desmente o facto de haver dados que comprovam que o sítio permanecia habitado durante a primeira metade do século I d.C. A comprová-lo está o fragmento que incluímos na variante $\mathrm{A}$ de Dressel-Lamboglia (fig. 12, $n^{\circ} 1$ ), que pode aparecer em contextos ligeiramente mais antigos, concretamente de finais do século I a.C. e primeiro quartel do seguinte (Morillo Cerdán 1999: 71). Este mesmo investigador, já alertou, contudo, que a cronologia inicialmente proposta por Loeschcke (1919), concretamente para o tipo IA aqui em causa, ainda que válida e seguida

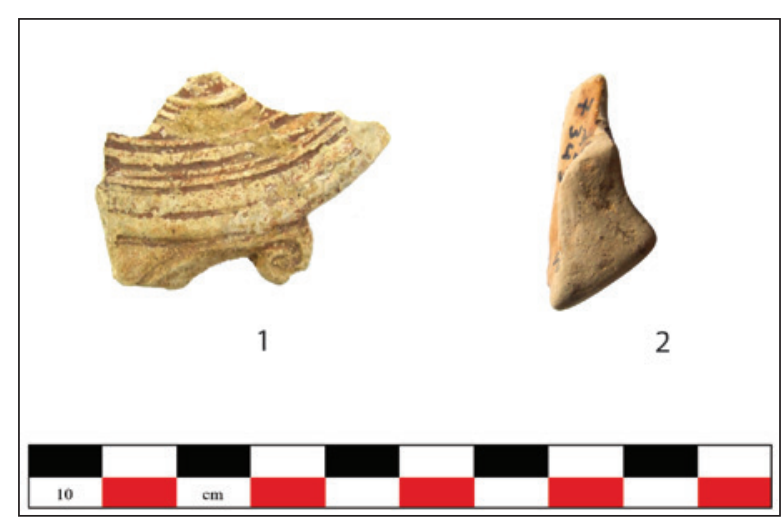

Figura 12. Lucernas do tipo Dressel-Lamboglia 9. por outros autores (Bussière 2000: 68; Casas-Genover e Soler-Fusté 2006: 106-107), pode ser susceptível de ligeiras alterações. Tal situação pode dever-se, entre outros motivos já prevenidos, à origem dos materiais analisados e localização geográfica do sítio onde foram utilizados. É possível que, tal como acontece na área setentrional da Península Ibérica (Morillo Cerdán 1999: 73), também este exemplar possa ser integrado numa datação preferentemente augustana.

Os restantes dois bicos, que, devido ao seu reduzido tamanho, não permitiram uma integração em uma das variantes, apresentam pastas que denunciam uma origem da área da Bética costeira (fig. 12, nº 2).

Os exemplares da forma Dressel-Lamboglia 11, compatíveis com os análogos Loeschcke IV, Ponsich IIB1, Deneauve VA, Walters 81-84, Bailey B-III e ainda com Bussière B III 1b, constituem uma das formas mais presentes nos sítios romanos imperiais. A grande inovação deste tipo reside no bico redondo, ladeado por volutas duplas, e, por vezes, a presença de asa (Dressel-Lamboglia 14). As restantes particularidades do tipo 9 são também aplicadas neste tipo, que convivem com o primeiro. Uma datação integrada na segunda metade do século I d.C. tem sido cada vez mais admitida para estas peças, particularmente no Extremo Ocidente peninsular, podendo, ainda assim, alcançar os primeiros anos da centúria seguinte. Porém, e apesar dos frequentes debates sobre a cronologia destas lucernas, já bem resumidos por alguns autores (Morillo Cerdán 1999: 87-89; Bussière 2000: 72-74; Casas-Genover e Soler-Fusté 2006: 124-125), continuam a persistir dúvidas relativamente à sua datação, uma vez que quer o âmbito geográfico quer a própria origem a podem condicionar. Em áreas distintas tanto a importação como a produção podem ser anteriores a meados do século I d.C., da mesma forma que o momento final do consumo/utilização pode variar, como aliás já tinha sido devidamente salientado (Morillo Cerdán 1999: 88).

No sítio do Monte Molião, apenas foram identificadas três lucernas incluíveis, indiscutivelmente, neste tipo (fig. 13). Esta classificação é avançada por ser seguro que nenhum deles tem asa na parte oposta ao bico. Trata-se de exemplares originários da Bética costeira, decorados, apresentando um deles a marca OPPI, acompanhada de contra-marca (fig. 13, $\mathrm{n}^{\mathrm{o}} 1$ ). Dois dos exemplares foram recolhidos em contexto, embora em níveis atribuíveis a diferentes fases. Ambos recolhidos no sector A, um é proveniente da unidade [85], que corresponde a um aterro que cobre parcialmente as estruturas da fase intermédia da época imperial ( $2^{\mathrm{a}}$ fase), estrato que pode ser datado de meados do século II, e o 


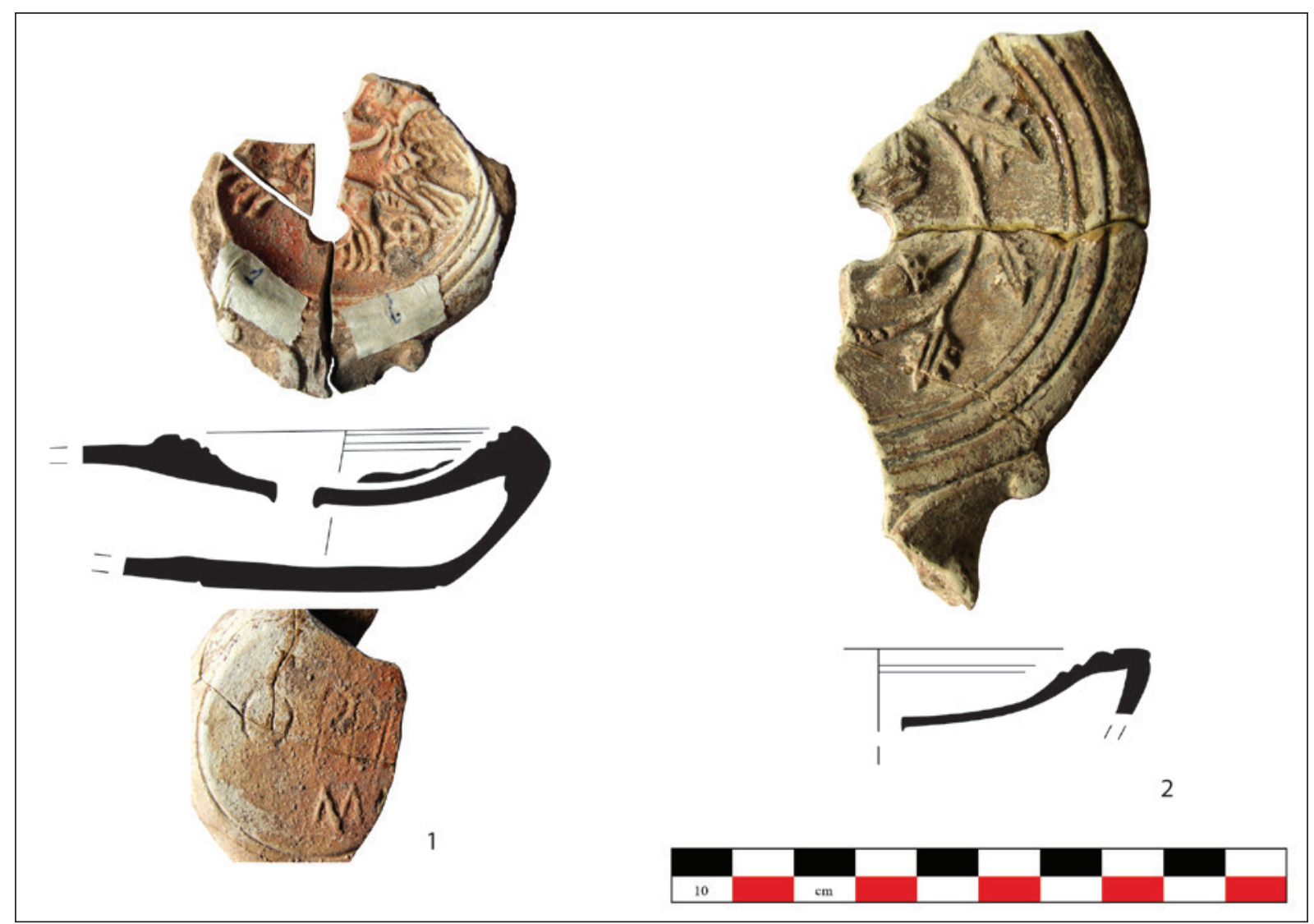

Figura 13. Lucernas do tipo Dressel-Lamboglia 11.

outro da U.E. [117], a que foi atribuía uma cronologia da segunda metade do século I d.C. A última é claramente da $1^{\text {a }}$ fase romana imperial do sítio, coincidindo com a datação da peça. Todavia, o fragmento exumado naquela unidade delata um considerável desfasamento entre a datação da forma e a do estrato. Cremos que esta situação se deve ao facto de a unidade estratigráfica conter um amplo conjunto de materiais de cronologias várias, sintoma de que as terras utilizadas na sua formação estavam já recheadas com materiais prévios, como pode ser o caso da lucerna.

Mas, como acontece com a maioria das lucernas da série de volutas, o seu estado de fragmentação é grande, o que dificulta a integração de muitos outros fragmentos em tipos específicos, concretamente 11 ou 14. Assim, e na impossibilidade de sabermos se as peças teriam, ou não, asa, fomos obrigados a uma classificação combinada: Dressel-Lamboglia 11/14. Neste tipo, incluímos 37 fragmentos, provenientes de ambos os sectores, A e C, exclusivamente originários da Bética costeira. As pastas são maioritariamente de tonalidade bege, ou bege acastanhada clara, e bastante polvorentas (sobre as pastas das lucernas e as propostas de origem, videm Pereira 2014: 10-15). A maioria não apresenta o engobe/verniz conservado, ainda que muitos tenham vestígios da sua existência.

Os contextos de recolha são muito diversos, o que se justifica pelo elevado número de exemplares. Ainda assim, cremos que a maioria das peças terá sido recolhida em contexto primário de deposição, estando de acordo com a datação que vem sendo outorgada a esta forma, segunda metade do século I d.C., alcançando os primeiros decénios do seguinte.

Como seria espectável, nos níveis da fase mais tardia apenas foi recolhido um restrito conjunto de 13 fragmentos, sendo admissível que alguns estariam em deposição secundária (fig. 23). De facto, a recolha destes artefactos em contextos tão tardios (segunda metade do século II) não está documentada em nenhum lugar (sobre o tema Videm Morillo Cerdán 1999: 88-89), devendo-se explicar a situação do Molião por factores diversos, que deturparam o seu contexto primário, concretamente 


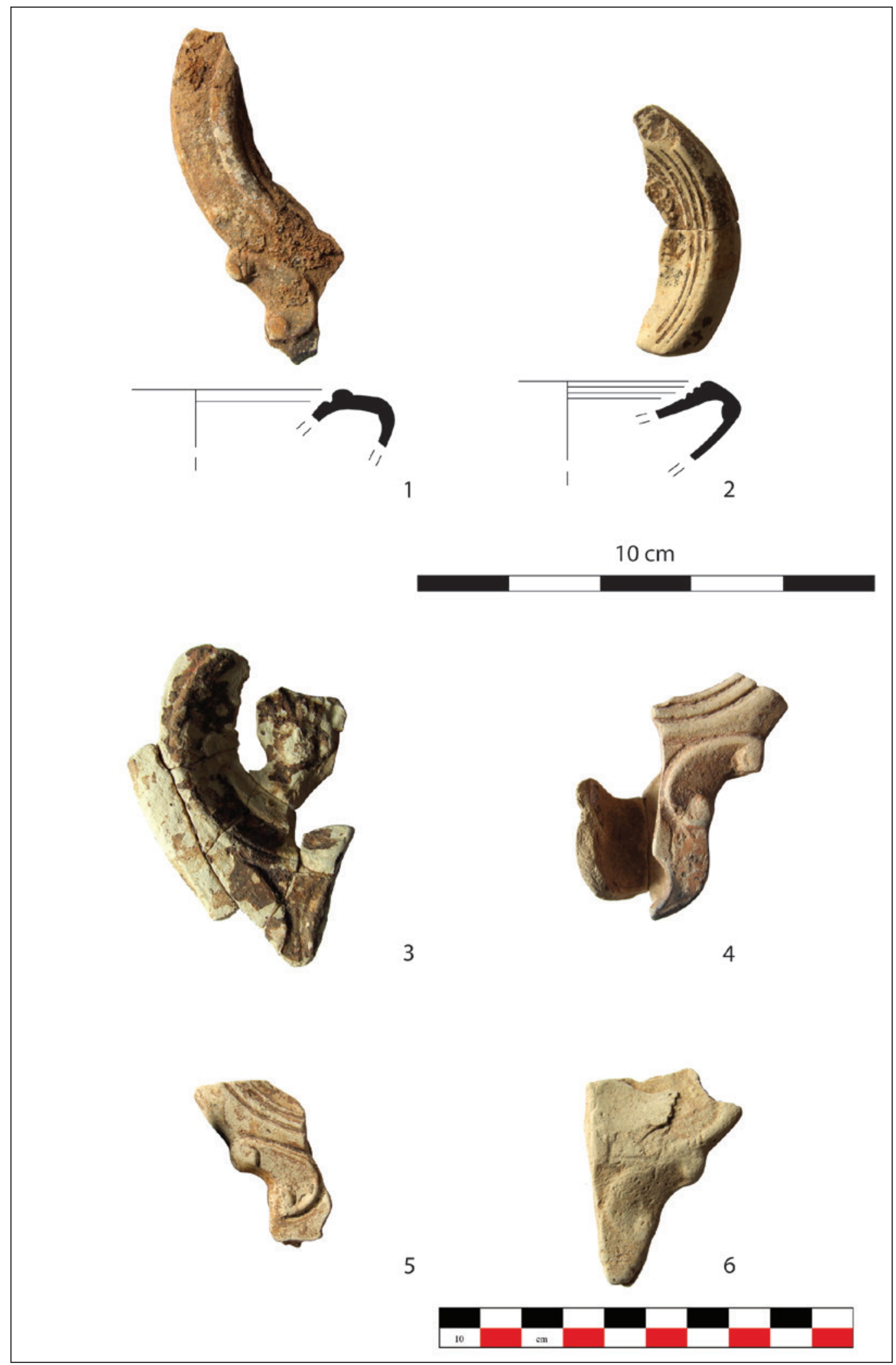

Figura 14. Lucernas do tipo Dressel-Lamboglia 11/14. 


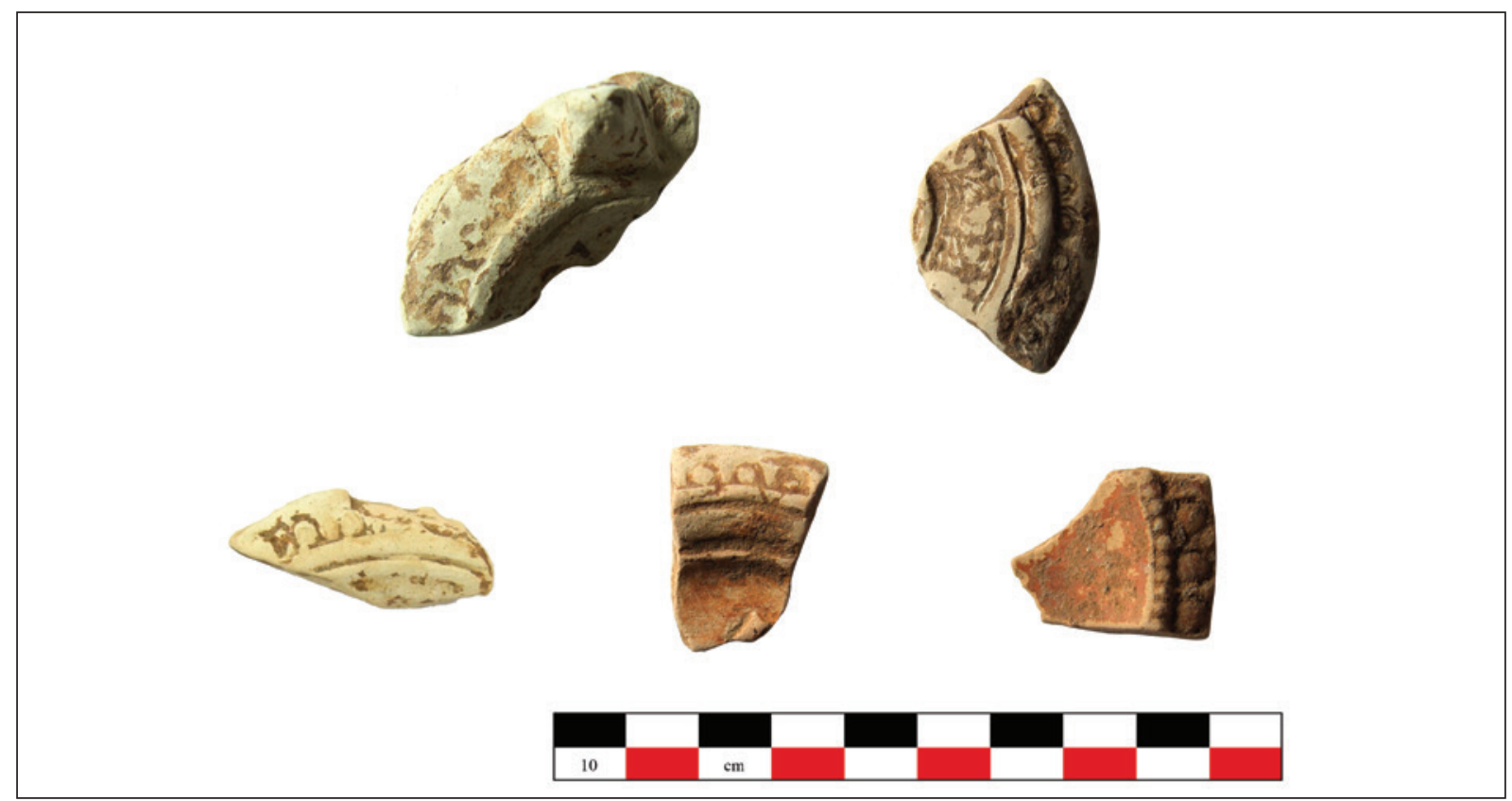

Figura 15. Lucernas do tipo Dressel-Lamboglia 16.

a movimentação de terras que deverá ser explicada pela constante manutenção/construção no sítio.

Os níveis da $2^{\mathrm{a}}$ fase são aqueles que mais fragmentos desta categoria forneceram. Não pode deixar de se estranhar esta preponderância num momento que vem sendo datado entre o final do século I e, sobretudo, a primeira metade do século II d.C. Ainda assim, não podemos esquecer que ambas as cronologias coincidem, em parte, apesar de esta primazia fazer mais sentido na fase ocupacional mais antiga, a qual corresponde, mais adequadamente, à datação que vem sendo atribuída a estas lucernas. Por outro lado, se tivermos em consideração a existência de duas produções com características distintas (Morillo Cerdán 1999: 87-88; Casas-Genover e Soler-Fusté 2006: 124), quer morfológicas quer cronológicas, reparamos que as lucernas do Monte Molião se enquadram na produção mais recente, da segunda metade do século I d.C. e primeiros decénios do seguinte. Corresponde a uma evolução da produção mais antiga do mesmo tipo, com o bico mais curto e volumoso, as orlas mais amplas e convexas e as volutas mais ajustadas ao bico, quase se unindo uma à outra. A tipologia que melhor define as características destas produções, e a evolução de uma para a outra, é a que foi elaborada por Jean Bussière para as lucernas norte-africanas da Argélia (2000: 73, Fig. 6).

Contemporânea deste tipo é a forma Dressel-Lamboglia 16, que, aliás, apresenta genericamente os mesmos traços morfológicos. As diferenças existentes entre os tipos 15/16 e os antecedentes 11/14 residem somente nas volutas, que deixam de ser duplas para existirem apenas no bico (Pereira 2014a: 28). É sempre muito difícil individualizar fragmentos destas formas num conjunto bastante fragmentado, como é o caso em análise. As orlas, a parte das lucernas mais comum nos sítios arqueológicos, ostentam as mesmas características, sendo ligeiramente convexas, por vezes horizontais, com duas ou três molduras e com o ombro bastante marcado. Dressel distinguiu os tipos 15 e 16 pela morfologia do corpo e pela presença ou ausência de decoração na orla. Porém, outros autores desmarcaram-se desta divisão tradicional, que, sempre ao abrigo das características volutas dos tipos 15 e 16 de Dressel-Lamboglia, criaram subgrupos, com base, sobretudo, na presença ou ausência de asa (Bussière 2000: 75-76, Fig. 6, tipos B IV 2 e B IV 3).

Ainda que este tipo de lucernas tenha convivido com o anterior, parece pacífico admitir que a sua cronologia vai para além dos primeiros decénios do século II d.C., concretamente até aos seus meados (Morillo Cerdán 1999: 92; Morais 2005: 322; Casas-Genover e Soler-Fusté 2006: 133-134).

Em Monte Molião, apenas identificámos cinco fragmentos pertencentes ao tipo Dressel-Lamboglia 16 (fig. 15), que apresentam orlas decoradas. Algumas das lisas podem ter pertencido ao tipo 15, mas, estando as volutas ausentes, tal identificação é impossível. Mais 
uma vez, as pastas denunciam uma clara origem da área litoral da Bética.

A estreita relação comercial que o Algarve manteve com a área de Cádis já foi por diversas vezes reconhecida, sendo evidente mesmo para momentos anteriores à época romana (Arruda 2005; 2007; Arruda e Pereira 2008; 2010; Fabião 2007; 2009; Gambelas 2009; Santos 1971; 1972; Sousa 2009; Sousa e Arruda 2010; Viegas 2007; 2011; apenas para citar alguns casos). Por outro lado, sabemos também que, desde cedo, esta região andaluza se assumiu como uma das mais dinâmicas no que à produção cerâmica e piscícola diz respeito, situação bem exposta nos recentes trabalhos de António Saez Romero $(2005 ;$ 2008; 2014).

Quanto aos contextos de recolha, a situação é idêntica à dos tipos precedentes. Convém salientar, contudo, que esta forma foi apenas recolhida em níveis que associámos à $2^{\mathrm{a}}$ fase imperial, tanto no sector $\mathrm{A}$ como no $\mathrm{C}$.

As lucernas do tipo "derivadas das Dressel-Lamboglia 9", mais conhecidas como "lucernas mineiras" (Luzon Nogué 1967) ou ainda tipo "Riotinto-Aljustrel" (Alarcão 1966: 26; Pereira 2014b: 122), também estão presentes neste sítio algarvio, havendo-se reconhecido seis exemplares (fig. 16).

Ainda que as lucernas deste tipo, recolhidas na necrópole de Valdoca, Aljustrel, tenham sido datadas de meados do século I d.C. (Andrade et al. 1957; Alarcão 1966: 26; Belchior 1970: 76-78), Luzón Nogué, estudando os exemplares de Riotinto, avançou a sua cronologia até à primeira metade da centúria seguinte (1967: 139-142). Desde então vêm sendo reconhecidos exemplares em contextos que permitiram afinar continuamente a cronologia desta produção de morfologia genuinamente hispânica, nomeadamente em Munigua (Raddatz 1973: 39), Huelva (Del Amo 1976: 92), Mina de la Peña del Hierro, Huelva (Bailey 1988: 175, Q 1667), e em outros sítios da Bética (Moreno Jiménez 1991: 132135), mas também em Ossonoba (Gamito 1992: 116) e em Mérida (Rodríguez Martín 2002: 25). Estes contextos permitiram datar estas lucernas dos séculos II e III (López Rodríguez 1981: 14; Morillo Cerdán 1999: 105).

A área de fabrico deste tipo de lucernas não levanta actualmente problemas de maior, sendo aceite, sem grandes reservas, que foram produzidas em centros oleiros do Sudoeste peninsular (Morillo Cerdán 1999: 105; Morillo Cerdán e Rodríguez Martín 2008: 301-302), onde, aliás, uma das marcas (L.I.R.) tem vindo a ser associada a Lucius Iulius Reburrinus, identificado no memorial da sua sepultura (Campos Carrasco et al. 2004: 126 e 140; Pérez Macías e Delgado Domínguez 2012: 316; Delgado Domínguez e Pérez Macías 2014: 407).
Também conhecidas como lucernas mineiras, conceito que actualmente não se adequa, convenientemente, à sua dispersão geográfica e à sua utilização em contextos de habitat (Pereira 2014b: 122), contextos onde, aliás, já se documentou também a sua produção (Vázquez Paz 2012: 422), serviam a função de recipiente robusto e resistente, adequado ao trabalho efectuado nas minas (Modrzewska 1992: 66). Contudo, estas características, talvez aliadas ao custo e à proximidade regional, favoreceram a sua gradual dispersão pela área central, sul e oeste da Península Ibérica, com especial concentração na área nuclear da produção. Todavia, alcançou também regiões mais setentrionais (Morillo Cerdán 1999: 105-106; Morais 2005: 342), embora em número reduzido e, aparentemente, em um momento ligeiramente mais tardio, e ainda o litoral do Norte de África (Morillo Cerdán 1999: 105).

Os contextos de recolha das peças do Monte Molião concordam, sobretudo, com uma cronologia do século II, concretamente da primeira metade. Não obstante, refira-se a recolha de um fragmento em um estrato, [108], que vem sendo considerado da segunda metade do século I d.C. Esta realidade confirma que, mesmo que a maioria das peças ofereça uma datação do século II, podem existir exemplares mais antigos, como é, aliás, defendido para a área onde foram produzidas (Delgado Domínguez e Pérez Macías 2014: 404). Afinal esta produção genuinamente hispânica baseou-se na morfologia do tipo Dressel-Lamboglia 9, característico da primeira metade do século I. Refira-se ainda que a sua produção neste mesmo século está perfeitamente atestada em um forno doméstico identificado na Plaza de la Encarnación, em Sevilha (Vázquez Paz 2012: 422), que, segundo o autor, não terá laborado além da década de 70 d.C.

Tal como as lucernas da série de volutas potenciaram a produção desta forma genuinamente hispânica, concretamente as de bico triangular (Morillo Cerdán 1999: 104-105; Morillo Cerdán e Rodríguez Martín 2008: 301-302; Pereira 2014b: 108-109), outras peças de fabrico hispânico demonstram características que transparecem uma inspiração nos protótipos itálicos, é o caso do tipo Andújar, lucernas também conhecidas como "derivadas da Dressel 3" (Morillo Cerdán 1999: 100-101; Morillo Cerdán e Rodríguez Martín 2008: 298-299). Embora já tivéssemos divulgado algumas lucernas que transpareciam pastas com características que delatavam esta origem (Pereira 2012a; 2013), ainda que correspondendo a imitações fidedignas, podemos agora afirmar com maior segurança que as típicas lucernas de tipo Andújar alcançaram sítios localizados no Extremo Ocidente. 


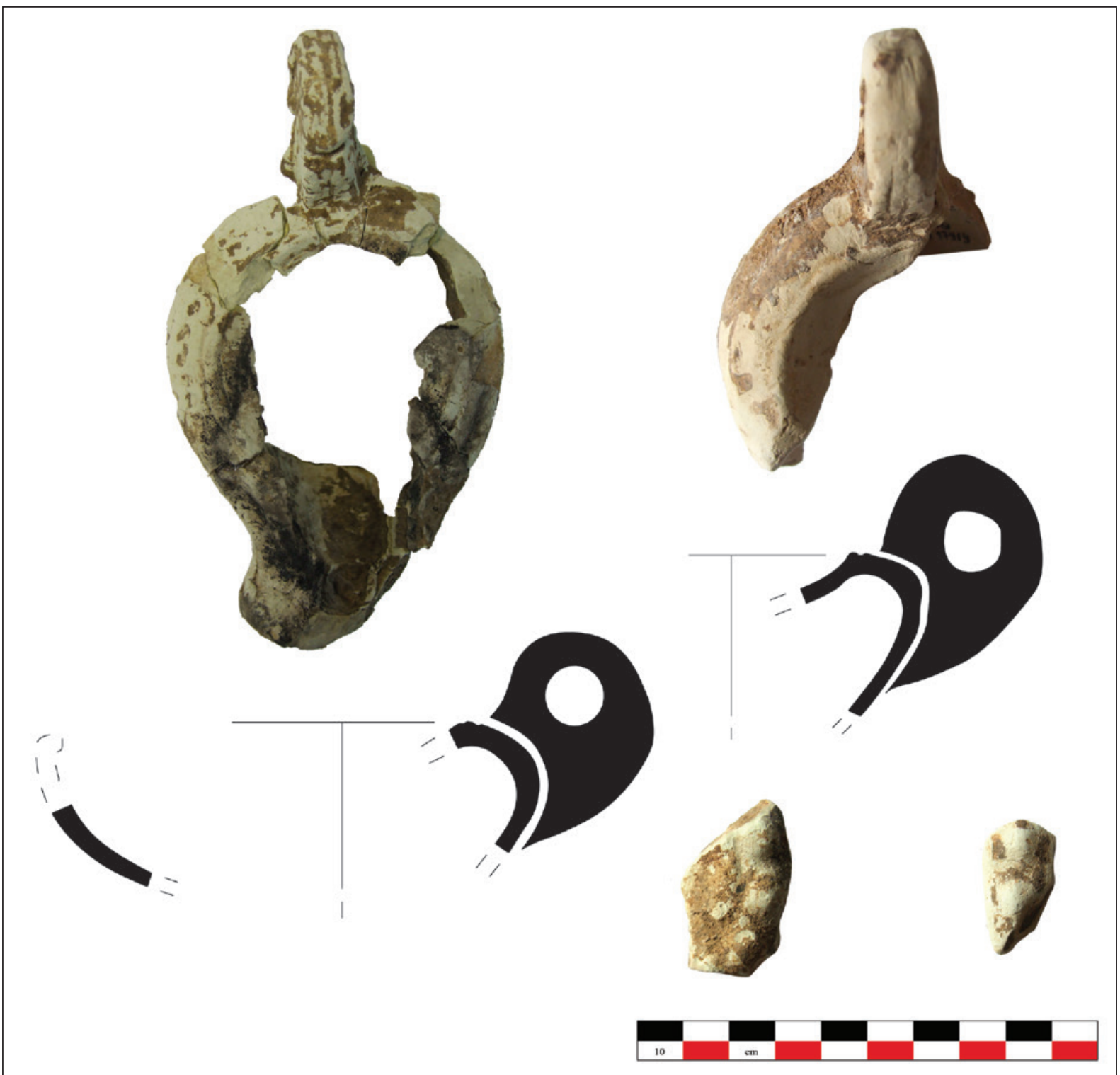

Figura 16. Lucernas de tipo Riotinto-Aljustrel.

Apresentam geralmente o corpo troncocónico de paredes altas e rectas, a orla bastante horizontal com duas molduras e duas aletas a cada lado. O bico tem uma forma mais ou menos triangular, com os extremos salientes, e no topo ostenta duas volutas em relevo (Morillo Cerdán e Rodríguez Martín 2008: 299). O disco é bastante côncavo e tem sempre representada uma concha de vieira.

As pastas de um exemplar do Monte Molião (fig. 17, $\mathrm{n}^{\circ}$ 1) encaixam naquelas descritas por Ángel Morillo Cerdán e Germán Rodríguez Martín (2008: 299), coincidindo com as pastas de tipo A já antes descritas em outro trabalho (García Giménez et al. 1999: 191). No entanto, a peça algarvia ostenta restos de um engobe espesso de tonalidade castanha muito escura ou negra. Note-se, contudo, que os autores apenas referem que a maioria das peças não tem qualquer revestimento, repetindo o que um deles já antes havia afirmado (Morillo Cerdán 1999: 100).

Outro exemplar (fig. 17, $\mathrm{n}^{\circ}$ 2) revela, todavia, características tecno-petrográficas que extravasam aquelas que as pastas mais comuns revelam. Trata-se de um fragmento de bico com as extremidades rematadas e com volutas, ainda que muito esbatidas, de pasta de tonalidade 


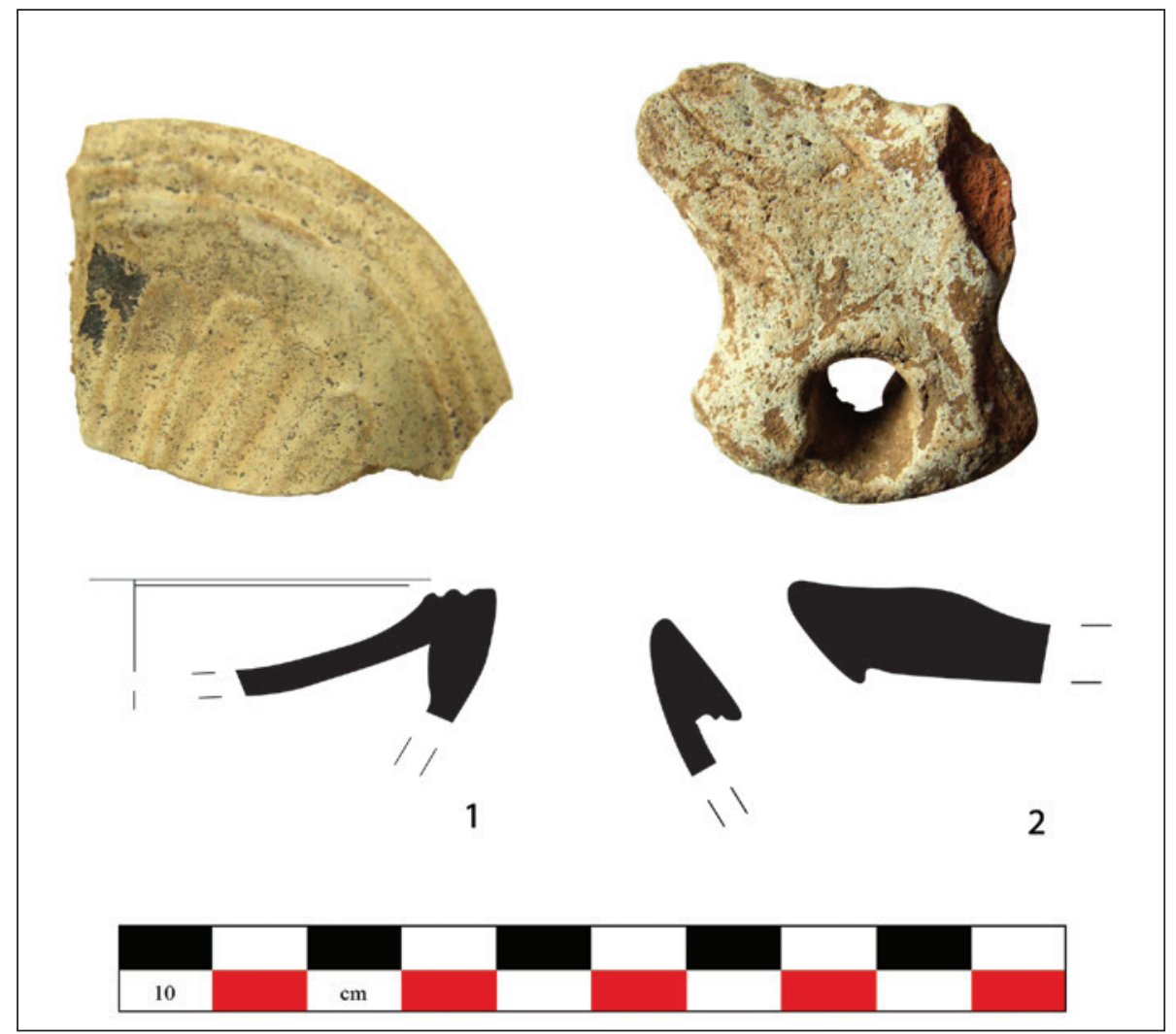

Figura 17. Fragmento de lucerna de tipo Andújar.

laranja avermelhada com a superfície esbranquiçada. Estamos, provavelmente, perante um fragmento de lucerna de tipo Andújar, que pode ter sido fabricado fora da Bética, talvez na capital da província da Lusitânia. Outros autores já haviam alertado para o facto de este tipo poder ter sido reproduzido em outras áreas da Península Ibérica (Morillo Cerdán 1999: 100), além de que, mesmo na província da Bética, desconhecemos ainda a totalidade dos centros produtores que terão produzido estas lucernas.

Ainda que esta forma seja preponderante durante a primeira metade do século I, foi já avançado que o final da sua produção pode alcançar o período flávio (Sotomayor et al. 1976: 135). Porém, o debate tem-se centrado sobretudo no início da sua produção, havendo autores que o situam no reinado de Tibério e outros que o avançam até ao de Cláudio (Morillo Cerdán 1999: 100). Embora não possamos precisar ainda a datação do exemplar de Monte Molião, pois foi recolhido na campanha de escavação do ano corrente e os restantes materiais associados não estão de momento convenientemente tratados, parece corresponder a um exemplar antigo, talvez do segundo quartel do século I d.C.

Não obstante, o fragmento de bico foi recolhido em um estrato que incluímos na $2^{\mathrm{a}}$ fase da ocupação imperial, sendo, portanto, mais tardio. Ainda assim, a relação entre estrato e artefacto parece estar de acordo, se considerarmos que o momento final de produção desta forma coincide com o momento inicial da ocupação da $2^{\mathrm{a}}$ fase. Efectivamente, tanto a qualidade do fabrico como as características das pastas, e a possível origem, remetem para uma produção tardia.

Tal como os exemplares de tipo Riotinto-Aljustrel, também o tipo Andújar gozou de uma ampla dispersão por toda a Península Ibérica, ainda que, compreensivelmente, com maior visibilidade na área meridional, onde acompanha a terra sigillata produzida no sítio epónimo. No Norte, fez-se representar em número considerável, devendo fazer-se notar que esta presença deve ser explicada pela ausência de produções lychnológicas que abastecessem as comunidades locais, uma vez que, nesta região, a terra sigillata produzida em Tricio estava plenamente assimilada (Morillo Cerdán 1999: 101-102). As lucernas de tipo Andújar seguiram, certamente, as principais vias Sul-Norte, acompanhando o azeite bético.

Efectivamente, a densa concentração de centros produtores nas áreas meridionais terá fomentado a maior produção de lucernas, também potenciada pela maior 
facilidade de acesso ao azeite para iluminação e ao seu baixo custo (Morillo Cerdán 1999: 101). Todavia, repetimos que o litoral algarvio mantinha, desde longa data, relações comerciais privilegiadas com essa região.

\subsubsection{Lucernas imperiais de disco}

As lucernas de disco são apenas três. Sendo esta série exclusiva do século II d.C., não deixa de ser curioso que a sua representatividade no conjunto lychnológico do sítio seja quase nula, 1,4\%. Como já dissemos na Introdução, o facto de a ocupação do Monte Molião se ter prolongado até momento avançado do século II (Viegas e Arruda 2013: 729-730) deveria traduzir-se numa presença mais efectiva de lucernas desta categoria, tal como acontece em outros sítios (Maia e Maia 1997: 36-37; Alarcão et al. 1976: 99; Rodríguez Martín 2002: 33; Morais 2005: 330).

Dos três fragmentos classificados nesta série, dois pertencem a exemplares da forma Dressel-Lamboglia 19 (fig. 18), com bico marcadamente distinto dos do tipo precedente. Apresentam pastas que denunciam uma origem da área da Bética costeira. São de tonalidade maioritariamente bege, bastante compactas, mas muito polvorentas (sobre a temática das pastas e das propostas sobre as suas origens, ver Pereira 2014: 10-15). Tal como sucedia com os exemplares de volutas, não conservam o engobe. A identificação deste tipo em concreto foi possível devido ao facto de a superfície do bico ser, geralmente, nivelada com o topo da orla.

Ainda que a maioria dos autores esteja de acordo com a cronologia que vem sendo proposta, primeira metade do século II (Loeschcke 1919: 51; Broneer 1930: 83-87; Bisi 1977: 88-95), alguns sugeriram outras datações para o início da produção ou mesmo para o seu momento final. Donald Bailey recuou o seu aparecimento para a época flávia (1980: 303), o que só pode ser defensável para o reinado de Domiciano, uma vez que é só a partir desse momento que os centros produtores estão relativamente bem documentados na área da Campânia ou no centro da Península Itálica (Pavolini 1977: 38; Cerulli 1977: 62-63). Naturalmente que para as produções provinciais a cronologia terá, obrigatoriamente, que avançar um pouco, mesmo que apenas ligeiramente.

Os contextos de recolha de ambos os fragmentos incluídos neste tipo estão de acordo com estes dados cronológicos. Foram exumados em níveis datados da primeira metade do século II, concretamente no

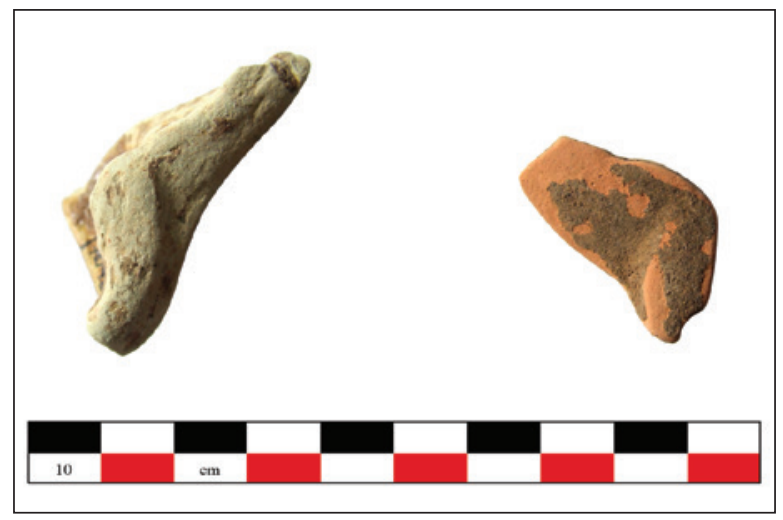

Figura 18. Lucernas do tipo Dressel-Lamboglia 19.

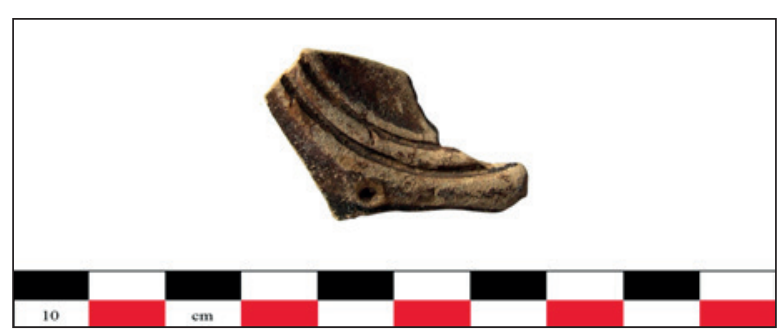

Figura 19. Lucerna do tipo Dressel-Lamboglia 20.

sector A, embora um deles seja proveniente de um estrato de aterro, U.E. [85], realidade que pode justificar a sua convivência com um abundante número de lucernas de tipo Dressel-Lamboglia 11/14, situação que já justificámos antes. Ainda assim, é evidente que ambas as formas conviveram durante algum tempo.

O restante fragmento da série de disco corresponde a um exemplar do tipo 20 (fig. 19), um dos mais comuns da série e, por isso mesmo, dos mais abundantes em sítios arqueológicos alto-imperiais (Morillo Cerdán 1999: 117). Apresenta a maioria das características do tipo anterior, diferenciando-se deste pelo facto de o bico se encontrar a um nível ligeiramente inferior, comparativamente à orla, ladeado por dois pontos em negativo. Quanto à cronologia, os diferentes investigadores parecem estar de acordo sobre o seu aparecimento ainda em finais do século I d.C., cronologia atestada em Pompeia e Vindonissa (Denauve 1969: 165), sendo também consensual o final da sua produção, na segunda metade do século seguinte. Verificamos, pois, que as questões levantadas para o tipo precedente podem também ser colocadas no âmbito desta forma, até porque, o fragmento lacobrigense, foi igualmente recolhido em um estrato da primeira metade do século II. 


\subsubsection{Lucernas imperiais de canal}

Menos comuns são as lucernas de canal do tipo Dressel-Lamboglia 5, equivalente ao $\mathrm{X}$ de Loeschcke (1919), também conhecido como Firmalampen (Fishback 1896: 11), caracterizadas por um bico mais alongado com um canal profundo, no topo, geralmente ligado ao disco. Ostenta ainda dois apêndices laterais, neste tipo em concreto, descentralizados. Nestas lucernas, o disco não está, geralmente decorado, e a decoração, quando presente, limita-se a representações de máscaras teatrais (Morillo Cerdán 1999: 127).

Comparativamente com as restantes formas identificadas, este tipo não é muito comum em território algarvio. Quando existe, faz-se representar em pequenas quantidades e em sítios com uma cronologia que abarca o século II d.C., ainda que o início da sua produção esteja documentado em momento centrado na segunda metade do século I d.C. (Morillo Cerdán 1999: 128). Esta escassez de Firmalampen não deixa de causar estranheza, principalmente tendo em conta que esta foi a primeira série cujas características permitiam o seu fabrico massivo (Morillo Cerdán 1999: 127), destinado a uma exportação de larga escala (Morillo Cerdán e Rodríguez Martín 2008: 297). Por outro lado, não se conhecem, no litoral andaluz, quaisquer centros produtores deste tipo. A sua produção está documentada em outras áreas, mais a Norte (Amaré Tafalla e García Marcos 1994; Amaré Tafalla et al. 1983; Díaz Trujillo 1988: 190; Morillo Cerdán 1999: 161-162; 2008: 298; Morais 2005: 373-374), obrigando a ponderar outra origem para as peças aqui tratadas.

Foram já ensaiadas explicações para este fenómeno, tendo Ángel Morillo resumido o debate sobre a pouca expressividade de lucernas de canal na área meridional da Península Ibérica (1999: 129), tomando em consideração as hipóteses avançadas por outros autores (Bailey 1980: 276; Pavolini 1987: 149). Embora a origem destas lucernas se localize no Norte de Itália, sabemos que foram exportadas para as províncias mais próximas, onde foram rapidamente imitadas, como foi o caso da Gália. O grande sucesso de que gozaram ampliou geograficamente a sua reprodução, tendo chegado ao norte da Península Ibérica (Casas-Genover e Soler-Fusté 2006: 170-171). O seu consumo não é, porém, homogéneo no Norte e Sul, sendo mais parco neste.

A coincidência produtiva, em termos cronológicos, de estas lucernas com os exemplares de disco poderá, segundo Morillo Cerdán, justificar a ausência daquelas na região Sul, o que se justificaria pela quebra na homogeneidade produtiva e comercial das lucernas da série de volutas, a partir deste momento. As três áreas do Império onde se produziram e comercializaram tipos lychnológicos distintos, seriam, assim, as seguintes:

"el Mediterraneo Occidental, dominado por los ejemplares de disco itálicos o africanos; el Norte de Italia y las províncias septentrionales del Imperio, cuyos mercados estan copados por las lucernas de canal; en tercer Iugar, Grecia y las provincias orientales, que siguen una evolución aparte con sus propias variedades de disco" (Op. Cit. 1999: 129).

Assim, distintas áreas, ou províncias do Império, foram influenciadas por diferentes regiões da Península Itálica, embora as peças mais comuns do Sul também tenham sido consumidas no Norte e vice-versa. Recordamos que a série de canal também está documentada, inclusive, no Norte de África (Bussière 2000: 84-85, Fig. 8). Além disso, deve-se salientar que a região meridional tinha já uma longa tradição de produção cerâmica, concretamente lucernas, fomentando um certo desfasamento relativamente aos produtos itálicos e inspirando-se, principalmente a partir de final do século II d.C., nos norte-africanos.

A análise preliminar das pastas efectuada por Ángel Morillo Cerdán, a quem agradecemos, confirmou que os exemplares de Molião não podem ser associados às figlinae do Norte. Por outro lado, as suas características excluem seguramente um fabrico bético, onde este tipo não deverá ter sido produzido. Assim, um dos exemplares (fig. 20, $\mathrm{n}^{\circ} 2$ ) pode corresponder a uma produção norte-itálica. Apresenta uma pasta compacta e homogénea, de tonalidade cor de tijolo, com poucos desengordurantes (quartzos, calcites), e tem engobe fino e de cor negro acinzentado.

$\mathrm{O}$ restante fragmento (fig. $20, \mathrm{n}^{\mathrm{o}} 1$ ) deve ser considerado de proveniência indeterminada. A pasta, de tonalidade bege, é muito compacta, homogénea e polvorenta. É muito bem depurada, contendo poucos e pequenos desengordurantes difíceis de distinguir com recurso a lupa de 14 aumentos, ostentando um engobe fino, cor-de-laranja.

Este tipo é, de facto, bastante raro no Sul da Lusitânia. Não obstante, a sua presença foi já referenciada em Ossonoba (Faro), neste caso uma única peça, de aparente fabrico bético (Pereira 2012a: 125), bem como na cidade de Balsa (Torre d’ Ares, Tavira) (Pereira 2014b: 121).

As peças lacobrigenses são provenientes de um estrato de aterro, a unidade [85], efectuado muito provavelmente em meados do século II d.C. 
Figura 20. Lucernas de canal do tipo Dressel-

Lamboglia 5, onde é visível o apêndice.

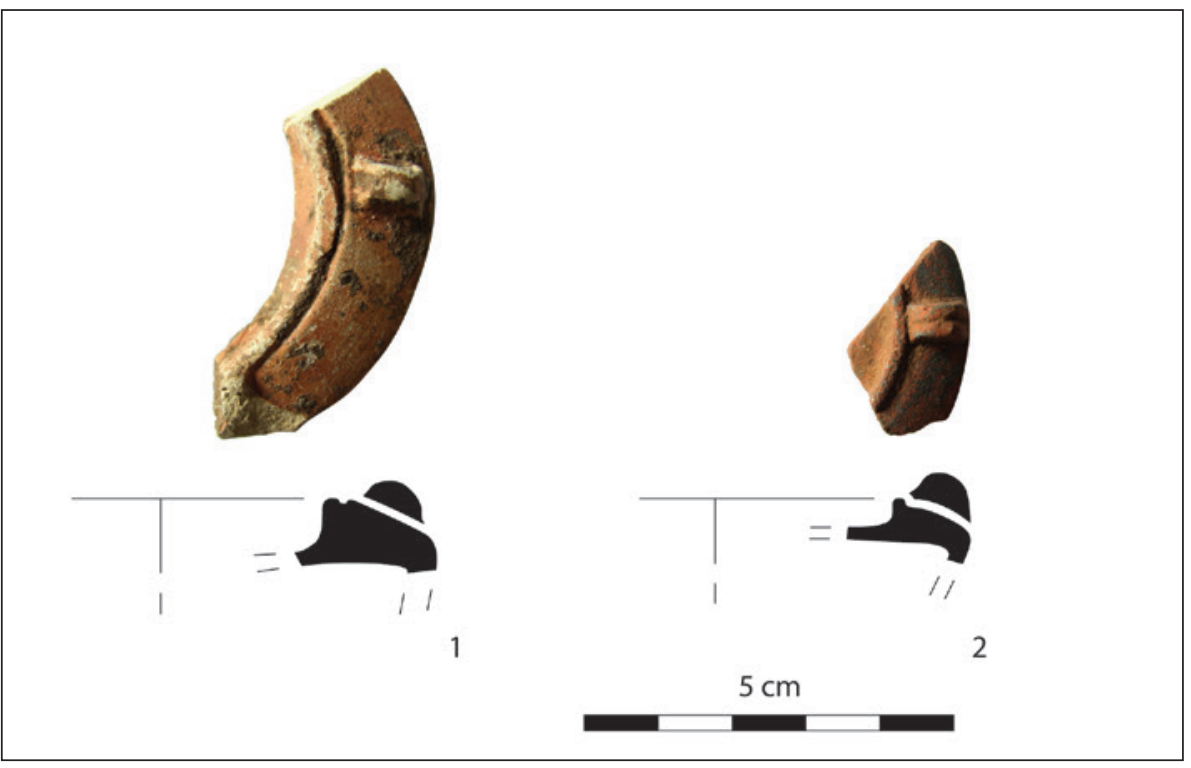

\subsubsection{Um tipo raro de lucerna}

Salientamos ainda a existência de um fragmento de asa correspondente a uma peça "bilychnis" (fig. 21), proveniente do mesmo estrato que a anterior, que classificámos do tipo Deneauve XC. Este tipo engloba peças de bico duplo justaposto, que podem ser da série de volutas ou de disco, geralmente com dois orifício de alimentação e uma asa centrada no disco, destinada à sua suspensão. Dada a variedade de tipos que esta forma pode incluir, como foi possível averiguar pelos análogos salacienses (Pereira 2013: 20-22), é difícil avançar com uma datação para um fragmento de dimensões tão reduzidas. Refira-se, ainda assim, a sua recolha no mesmo nível das peças antes tratadas, podendo ser aceitável uma datação da primeira metade/ meados do século II d.C.

\subsection{Iconografia}

Como é usual em conjuntos tão fragmentados, é grande a quantidade de fragmentos de disco que não permitem a leitura da decoração que ostentavam.

Da totalidade do conjunto (214 peças), pudemos identificar 24 fragmentos que apresentam decorações no disco ou na orla, dos quais apenas sete permitiram uma identificação dos motivos iconográficos representados no disco.

As decorações das orlas correspondem a formas geométricas e resumem-se a semicírculos virados para

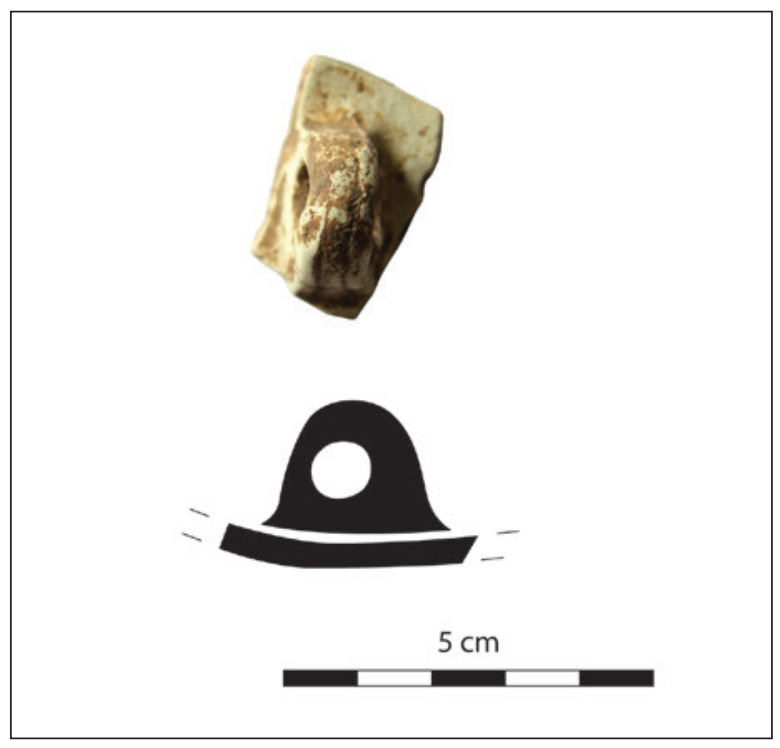

Figura 21. Fragmento de lucerna "bilychnis".

as molduras (fig. 15), óvulos em relevo (fig. 16) ou mesmo a junção das duas técnicas (fig. 15). Os mesmos óvulos aparecem em exemplares de tipo Riotinto-Aljustrel, também em negativo (fig. 16). Com efeito, esta é uma das formas onde a orla é decorada com óvulos em relevo e em negativo. Os restantes fragmentos correspondem a peças do tipo Dressel-Lamboglia 16.

Dos discos decorados, um ostenta o busto de Hélios (fig. 22, $\mathrm{n}^{\circ} 1$ ), de frente e coroado por raios. Sob o busto está o crescente lunar. Tal figuração, correspondente 


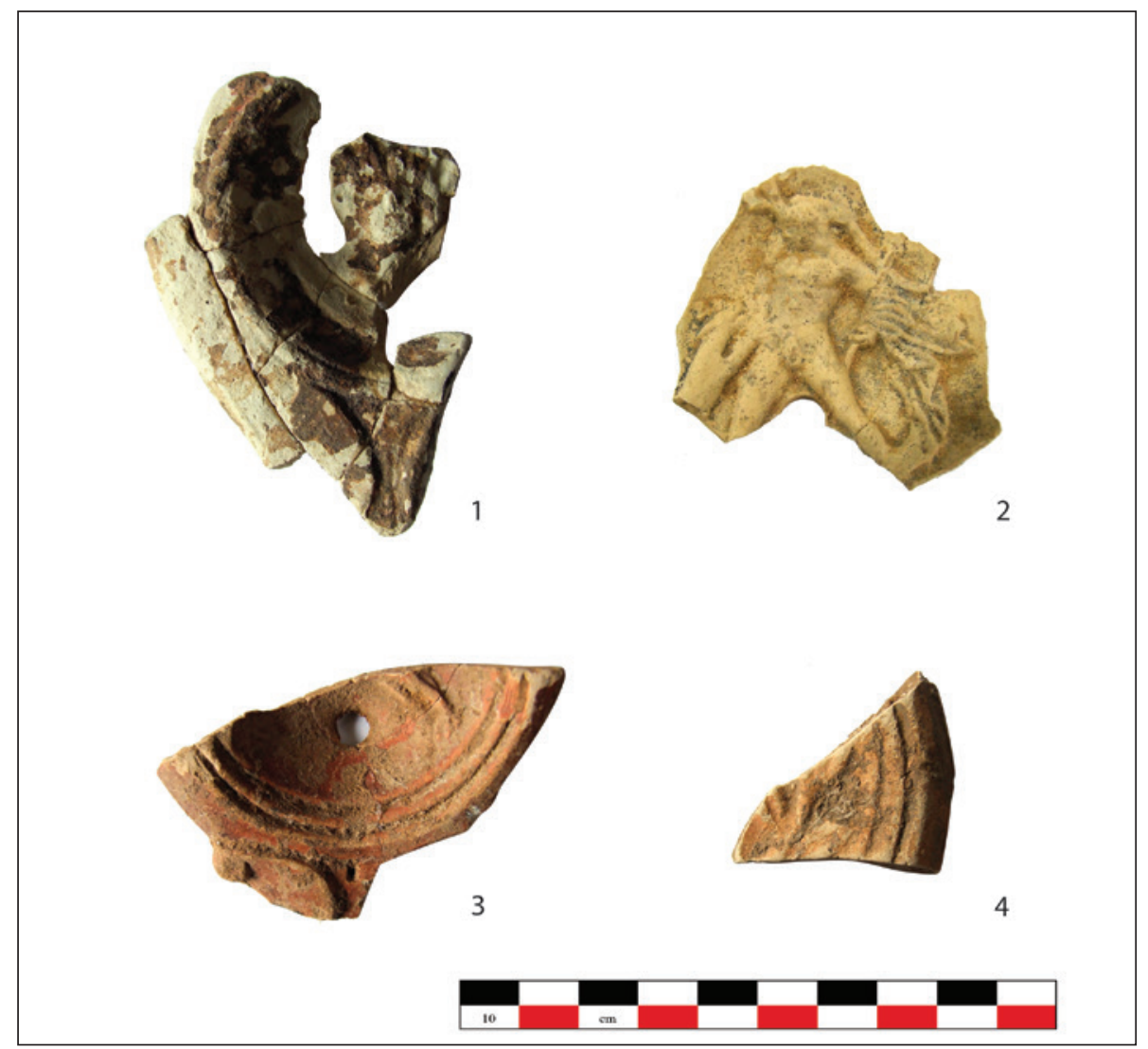

Figura 22. Fragmentos de disco de lucernas com motivos decorativos.

a uma divindade menor (Morillo Cerdán 1999: 180), está efectuada sobre uma lucerna pertencente ao tipo Dressel-Lamboglia 11/14, forma na qual este motivo não é particularmente comum. $O$ culto a esta divindade parece ter ganho especial alento durante o século II d.C., muito potenciado pela influência das religiões orientais (Lozano 1995: 126 apud in Morillo Cerdán 1999: 180). Não obstante, devemos ter em consideração que este tipo de lucerna está sobretudo datado do século I, mesmo que possa ter sido fabricada no(s) primeiro(s) decénio(s) desta centúria. Por outro lado, a existência deste culto ainda no século I d.C. também não é completamente improvável (Ibidem). Ambos os factos permitem assim esbater as aparentes incompatibilidades cronológicas entre a forma da lucerna e o culto. $\mathrm{O}$ certo é que a maioria das representações de Hélios pode ser encontrada em formas mais tardias, da série de disco.

Em Mérida, pudemos documentar a existência de um exemplar análogo, tanto na forma como na iconografia, que concorda com a cronologia avançada (Rodríguez Martín 2002: 67-68, Fig. V, no 61). Refiram-se ainda outros, de Cartago (Deneauve 1969: XXXV, $\mathrm{n}^{\mathrm{o}}$ 282), de Conímbriga (Belchior 1969: 53, $\mathrm{n}^{\mathrm{o}}$ 10), de Peroguarda (Viana e Nunes 1956: 37), de Cádis (Moreno Jiménez 1991: 406), de Itálica (Moreno Jiménez 1991: 476, no 3340, 3341, 3111 e 3367), de Regina (Moreno Jiménez 1991: nº 2268), por exemplo.

Uma outra lucerna, da mesma forma, ostenta a representação de uma biga (fig. $13, \mathrm{n}^{\circ} 1$ ), que pode ser incluída na categoria de quotidiano e subcategoria de cenas de circo. Não obstante, a personagem que conduz a biga parece ter os típicos atributos de Victória alada, o que obriga à sua inclusão na categoria de divindades menores. De facto, a personagem parece vestir o peplos, insuflado pelo ar, e tem as típicas asas. Não é estranha a existência de uma representação de Victória sobre uma biga, principalmente se tivermos em consideração que esta divindade personifica o triunfo. Não obstante, a representação da divindade sobre a biga é bastante rara

Correspondente à categoria de mitos e lendas é um fragmento de disco, infelizmente inclassificável quanto à forma, que ostenta a representação de Actéon (fig. 22, $\mathrm{n}^{\mathrm{o}} 2$ ). Neste relevo, Actéon tenta libertar-se da sua própria matilha que, não reconhecendo o dono, o ataca. 
Esta situação advém da maldição que lhe foi evocada por Artemis, que o transformou em cervo como castigo por a ter espreitado enquanto se banhava (Grimal 1999: 5). Alguns autores consideram que a matilha era de Diana (Morillo Cerdán 1999: 192; Casas-Genover e Soler-Fusté 2006: 15). O que vemos é, precisamente, o início da transformação de Actéon, nu e em posição de defesa. Tenta proteger-se de um cão com o braço direito, e, no esquerdo, segura uma lança e a capa, que lhe cai. Podemos apreciar que tem já as hastes de cervídeo, que pendem para ambos os lados da cabeça.

Embora não possamos decifrar qual a forma a que pertenceu este fragmento, é consensual que esta representação é frequente sobretudo no século I d.C. (Bailey 1988: 771; Deneauve 1969: nº 286; Morillo Cerdán 1999: 192), pelo que seguramente terá pertencido a um exemplar da série de volutas. A sua grande dispersão pode ser sintomática da grande fama de que gozou na Antiguidade, sendo reconhecida desde a região mais ocidental do Império até à mais oriental (Morillo Cerdán 1999: 192), e da sua ampla diacronia, concretamente desde o reinado de Augusto até final do século I d.C. Atendendo ao contexto de recolha e aos paralelos reconhecidos (Casas-Genover e Soler-Fusté 2006: 15, G59), pode ser admissível uma datação em torno ao reinado de Tibério.

Se considerarmos que este fragmento pode, eventualmente, ter pertencido a uma lucerna do tipo Dressel/Lamboglia 9, não é improvável que seja originário da figlina doméstica que foi recentemente identificada em Sevilha (Vázquez Paz 2012). De facto, parece compartir afinidades, quer iconográficas quer tecno-petrográficas, com os artefactos produzidos nesse forno.

Outro fragmento de disco ostenta um animal em corrida (fig. 22, no 3 ). Infelizmente, não podemos assegurar a que animal corresponde, podendo tratar-se tanto de um javali, como de um urso ou de um cão. A peça corresponde a uma forma da série de volutas, provavelmente do tipo Dressel-Lamboglia 11 ou 14.

Relembramos a existência da lucerna de tipo Andújar, com a representação de uma concha de vieira, que permite a sua inclusão na categoria da fauna (fig. 17).

$\mathrm{Na}$ categoria da flora, pudemos incluir dois fragmentos de disco, que ostentam uma coroa de carvalho (fig. 13, $n^{\circ} 2$ ) e uma coroa de loureiro (fig. 22, $n^{\circ} 4$ ). As coroas vegetais constituem um dos principais temas nas representações florais (Pereira 2008: 91). O primeiro caso foi possível de identificar devido à maior dimensão do fragmento e, também, pelo facto de a coroa ostentar uma bolota. No segundo, foi a forma da folha que permitiu a nossa interpretação.

\subsection{Epigrafia}

As marcas epigráficas são, comparativamente com o número total de lucernas, em número bastante reduzido. Apenas tivemos oportunidade de identificar quatro exemplares que tiveram, outrora, a marca do oleiro ou da figlina. O exemplar decorado com Victoria alada a conduzir a biga tem, na base, a marca OPPI em negativo (fig. 13, $\mathrm{n}^{\circ} 1$ ). Sob a marca, em relevo, está a letra "M", que pode tratar-se de uma contra-marca.

Esta marca não oferece hoje quaisquer dúvidas quanto à sua interpretação, estando a actividade desta oficina documentada desde o período flávio até meados ou finais do séc. II d.C. No entanto, é frequente depararmo-nos com variantes que apresentam um enquadramento cronológico mais preciso, como é o caso da marca COPPIRES, firmada em exemplares do tipo 11, ou da marca COR, efectuada sobre exemplares do tipo 20, mais tardios (Morillo Cerdán 1999: 300) e que podem corresponder a distintas gerações da mesma gens. Sabemos, actualmente, que esta foi uma das figlinae que disseminou os seus produtos por uma área ampla do Império. Fabricada inicialmente na Península Itálica, rapidamente foi reproduzida no Norte de África e também na Gália, concretamente em Montans (Berges 1989: 110; Morillo Cerdán 1999: 300).

No entanto, e no caso concreto da área meridional hispânica, estes artefactos têm características que permitem supor a sua produção na província da Bética, onde, aliás, são abundantíssimos, como se vem reiterando. Contudo, não é claro se esta situação resulta da cópia dos produtos de Caius Oppius Restitutus ou, pelo contrário, é o próprio que tem filiais nessa zona, que reproduzem os seus artigos originais (Joly 1974: 89). O certo é que a região oferece uma abundante quantidade destas marcas (Franco 1970: 16; Fernández Chicarro 1954: 62; Fernández Gómez e Hurtado Rodríguez 1991: 35-36; Moreno Jiménez 1991: 243-247; Balil 1965-66: 117-123; Amaré Tafalla 1989-90: 135-172).

Os três restantes fragmentos não permitiram, infelizmente, uma leitura satisfatória das marcas, o que fica a dever-se ao facto de conservarem apenas uma pequena parte desta. Refira-se, todavia, a possibilidade de duas poderem tratar-se de marcas de CIVNDRAC ou CIVNALEX.

\section{CONCLUSÃO}

O conjunto de lucernas de Monte Molião merece ainda um comentário final, que, de alguma forma, recupera muitas das observações que foram feitas ao longo do texto. 
Sobre as questões de cronologia, gostaríamos de chamar a atenção para o facto de não terem sido as lucernas que dataram os contextos ou faseamentos ocupacionais. Mas, por outro lado, também não foram as fases que permitiram atribuir uma cronologia concreta às lucernas. Foram afinal os contextos, na sua globalidade, concretamente na associação de materiais que reconhecemos nas diversas Unidades Estratigráficas e na posição relativa destas últimas na sequência estratigráfica, que contribuíram decisivamente para afinar a datação das lucernas consumidas neste sítio arqueológico. De facto, e embora as lucernas sejam muitas vezes consideradas verdadeiros "fósseis directores", a verdade é que quando se recuperam em contextos estratigráficos tão precisos, como é o caso em análise, são estes que devem sobrevalorizar-se. Assim, sendo verdade que em alguns casos as lucernas contribuíram para o acerto das datações das fases, também é certo que, em outros, foram estas e os restantes materiais a elas associados que permitiram considerar como materiais intrusivos algumas lucernas.

No entanto, não podemos deixar de registar que nem todos os dados lychnológicos parecem estar de acordo com os obtidos através da leitura global dos contextos. Esta situação pode ficar a dever-se a factores de natureza diversa, e que condicionam a leitura dos dados, como é o caso das movimentações de terras em época antiga, situação que foi detectada, particularmente, em estratos da $2^{a}$ fase imperial. Ainda assim, os dados de Monte Molião contribuem, na nossa perspectiva, para afinar a cronologia de alguns tipos lychnológicos, concretamente da série de volutas.

Queremos também destacar a escassez de exemplares de época republicana, o que, em nosso entender, pode justificar-se com a própria dinâmica ocupacional do sítio. Como já se fez referência em trabalhos anteriores, a ocupação republicana do Monte Molião não segue o padrão, geralmente, detectado na maioria de sítios de idêntica cronologia (Arruda 2007; Arruda e Pereira 2010; Arruda e Sousa 2012; Dias 2010). O sítio sofreu uma quebra acentuada nas importações a partir de meados da primeira metade do século I a.C., situação que pode ter-se reflectido na importação de lucernas, num momento em que estes materiais começavam a generalizar-se nos sítios do Extremo Ocidente peninsular. Porém, não devemos ignorar que esta situação lychnológica é comum à generalidade dos sítios algarvios, parecendo fazer sentido recordar que, mesmo em momento avançado do período republicano, é nos sítios de carácter militar que este tipo de artefacto é mais significativo em termos numéricos, como concluíram outros investigadores (Romero Carnicero 1990: 287; Nunes et al. 1990: 85; Morillo Cerdán 1999: 333-334; Betriu 2008: 89-90), e sobretudo em regiões mais setentrionais (Morillo Cerdán 1999: 65-66; 2008: 174175). A identificação de lucernas em sítios de habitat no Sul de Portugal tem sido meramente pontual. No entanto, quando se reconheceram conjuntos mais numerosos, a ocupação está sempre e claramente relacionada com uma função militar, como acontece no Castelo da Lousa (Morais 2010: 173-180), em Cabeça de Vaiamonte (Fabião 1998: 432), e, mais a Norte, na Alcáçova de Santarém (Pereira 2014: 49-50), na Lomba do Canho (Nunes et al. 1990: 71), e ainda em sítios emblemáticos como Cáceres el Viejo ou os acampamentos de Numância (Ulbert 1984; Romero Carnicero 1990, respectivamente).

A relação entre a presença dos exércitos romanos e o abundante consumo de lucernas é pois evidente, relação que foi já bem estabelecida para o Norte da Península Ibérica (Morillo Cerdán 2008: 174-175), ainda que neste caso para um momento mais tardio.

A presença de lucernas em contextos republicanos “...implica uma estreita ligação com correntes comerciais de longo alcance, uma vez que ofabrico deste tipo de utensilios, [...], exige conhecimentos técnicos que, na prática, impediam a sua imitação local" (Nunes et al. 1990: 85), o que explica o facto de a sua esmagadora maioria ser de importação. Por outro lado, as produções actualmente conhecidas em território hispânico estão também relacionadas com presença militar, como é o caso de Herrera de Pisuerga (Morillo Cerdán 1999: 6566). Contudo, a recolha de lucernas com pastas locais ou regionais não é inédita, como foi reconhecido na Alcáçova de Santarém (Pereira 2014: 21), uma vez que com os exércitos também se movimentavam artesãos que satisfaziam as suas exigências, particularmente em sítios de implantação litoral ou estuarina.

Porém, permanece por justificar a presença pontual de lucernas romanas-republicanas em sítios aparentemente de habitat, como é o caso do Monte Molião, apesar de não podermos excluir, à partida, uma eventual presença militar no sítio, principalmente se tivermos em consideração o episódico cerco a Laccobriga, durante as guerras sertorianas, e a possível relação deste topónimo com o sítio que aqui tratamos.

Tal como se verifica em outras categorias cerâmicas do sítio (Arruda e Sousa 2012), as lucernas permaneceram numa situação comercial constritiva, que se mantém até, pelo menos, meados do século I d.C., o que justificará o reduzido número também de exemplares da série de volutas de bico triangular (quatro exemplares). 


\begin{tabular}{|l|c|c|c|c|c|}
\cline { 2 - 6 } \multicolumn{1}{c|}{} & Itálicas & Béticas & Locais/Reg. & Indet. & Total \\
\hline Republicanas & 1 & 2 & & 4 & 7 \\
\hline De Volutas & & 81 & & 2 & 3 \\
\hline De Disco & & 3 & & 1 & 2 \\
\hline De Canal & 1 & 1 & & & 118 \\
\hline Bilychnis & & 108 & 2 & 15 & $\mathbf{2 1 4}$ \\
\hline Indet. & 2 & 195 & 2 & & \\
\hline \multicolumn{1}{c|}{ Total } & & & & & \\
\hline
\end{tabular}

Figura 23. Distribuição das diferentes produções identificadas.

Interpretar esta situação, verificável quer na importação de cerâmicas de iluminação, quer na das restantes categorias cerâmicas, não é fácil, tendo sido já proposto que o episódio descrito por Plutarco relativo às guerras sertorianas possa ser responsável por ela, no que diz respeito ao final da época republicana (Arruda e Sousa 2012: 130), o que, evidentemente, presume a assunção de que Monte Molião corresponde à Laccobriga das fontes clássicas. Todavia, permanece por constatar se este mesmo motivo poderá justificar a dilatação da mesma realidade até meados da centúria seguinte.

Em meados do século I d.C., contudo, o núcleo urbano algarvio parece recuperar do relativo marasmo em que se encontrava. A partir da época flávia, ou talvez mesmo ainda a partir do final do reinado de Cláudio, as lucernas de volutas de bico redondo devem ter sido massivamente consumidas, sendo a esmagadora maioria proveniente da província da Bética (fig. 23). Mais uma vez, as longas relações comerciais da costa litoral andaluza e portuguesa estão na base da justificação para a predominância massiva dos produtos béticos no Algarve. O seu transporte por via marítima, que seguramente seria efectivado em tempo relativamente curto, permitia a sua aquisição a preços bastante competitivos, não justificando o estabelecimento de centros produtores locais especializados. Aliás, só muito pontualmente encontramos, no Algarve, sítios com lucernas fabricadas localmente, mas que, mesmo assim, não delatam a existência de produtores lychnológicos.

Tendo em conta a elevada quantidade de materiais provenientes da área peninsular meridional, não é de estranhar que a mesma situação seja apurada para as lucernas. Porém, ao invés das ânforas, ou mesmo da cerâmica comum, tem sido difícil identificar as figlinae que se dedicaram ao fabrico destes utensílios. As justificações por detrás desta situação podem ser vários, nomeadamente o facto de serem fabricadas conjuntamente com outros materiais (Pereira 2014a: 2-3). No entanto, é cada vez mais evidente que as lucernas foram maioritariamente produzidas em âmbitos domésticos (Vázquez Paz 2012), que, embora transparecendo uma clara especialização, podiam escoar o produto para áreas mais distantes, através de intermediários. Não é improvável, com efeito, como acontecia com os produtos derivados de peixe (García Vargas 2006: 559560), a existência de comerciantes dedicados à compra/ venda de cerâmicas. Estando, portanto, na maioria dos casos, separada a produção da comercialização, melhor compreendemos que algumas olarias, domésticas e urbanas, tenham logrado uma considerável disseminação dos seus produtos, da qual os comerciantes eram os principais responsáveis. Esta proposta é bastante provável para o sul da Península Ibérica.

Atendendo aos contextos de recolha das lucernas de volutas, verifica-se que a maioria é proveniente de estratos da segunda metade do século I d.C. e início/primeira metade do século seguinte (fig. 24 e 25). Evidentemente que os da $1^{\text {a }}$ fase encaixam convenientemente com a cronologia das próprias lucernas. Não podemos contudo deixar de referir que a maioria de esses contextos correspondem ao final da utilização dos edifícios construídos no terceiro quartel do século I d.C., e que estes poderão ter estado em funcionamento até ao final do mesmo século. Desta forma, a cronologia destas lucernas pode, e deve, ser aqui entendida como um terminus post quem que marca o momento final de utilização das 


\section{Sector A}

\begin{tabular}{|c|c|c|c|c|c|}
\hline $\begin{array}{c}\text { Unidade } \\
\text { estratigráfica }\end{array}$ & $\begin{array}{c}\mathrm{N}^{\mathrm{o}} \text { de } \\
\text { fragmentos }\end{array}$ & Fase & Formas & $\begin{array}{l}\text { Cronologia } \\
\text { da fase }\end{array}$ & $\begin{array}{l}\text { Cronologia } \\
\text { da forma }\end{array}$ \\
\hline 0000 & 2 & & Indeterminadas & Nível de sup. & $? ? ?$ \\
\hline 0001 & 1 & & D-L 11/14 & Nível de sup. & $2^{\mathrm{a}}$ met. do I \\
\hline 0002 & 4 & & D-L 11/14 & Níveis de sup. & $2^{\text {a }}$ met. do I \\
\hline 0005 & 4 & & D-L 11/14 & Níveis de sup. & $2^{\mathrm{a}}$ met. do I \\
\hline 0008 & 2 & & D-L 9 e 16 & Níveis de sup. & $\begin{array}{l}1^{\mathrm{a}} \text { met. do I e } \\
2^{\mathrm{a}} \text { met. do I }\end{array}$ \\
\hline 0031 & 1 & & D-L 11/14 & Níveis de sup. & $2^{\mathrm{a}}$ met. do I \\
\hline 0028 & 6 & $3^{\mathrm{a}}$ fase & $\begin{array}{c}\text { D-L 11/14, } \\
\text { Riotinto-Aljustrel }\end{array}$ & $2^{\mathrm{a}}$ met. do II & $2^{\mathrm{a}}$ met. do I e séc. II \\
\hline 0050 & 1 & $3^{\mathrm{a}}$ fase & Indeterminada & $2^{\mathrm{a}}$ met. do II & $? ? ?$ \\
\hline 0055 & 1 & $3^{\mathrm{a}}$ fase & Indeterminada & $2^{\mathrm{a}}$ met. do II & $? ? ?$ \\
\hline 0058 & 3 & $3^{\mathrm{a}}$ fase & $\begin{array}{c}\text { D-L 11/14, } \\
\text { Riotinto-Aljustrel }\end{array}$ & $2^{\mathrm{a}}$ met. do II & $2^{\mathrm{a}}$ met. do I e séc. II \\
\hline 0059 & 1 & $3^{\mathrm{a}}$ fase & D-L 16 & $2^{\mathrm{a}}$ met. do II & $2^{\text {a }}$ met. do I \\
\hline 0063 & 1 & $3^{\mathrm{a}}$ fase & D-L 11/14 & $2^{\mathrm{a}}$ met. do II & $2^{\mathrm{a}}$ met. do I \\
\hline 0070 & 1 & $2^{\mathrm{a}}$ fase & Riotinto-Aljustrel & $\begin{array}{l}\text { Final do I e } \\
1^{\mathrm{a}} \text { met. do II }\end{array}$ & séc. II \\
\hline 0085 & 11 & $2^{\mathrm{a}}$ fase & $\begin{array}{c}\text { D-L 11, 11/14, } \\
\text { Riotinto-Aljustrel }\end{array}$ & $\begin{array}{l}\text { Final do I e } \\
1^{\text {a }} \text { met. do II }\end{array}$ & $2^{\mathrm{a}}$ met. do I e séc. II \\
\hline 0106 & 1 & $2^{\mathrm{a}}$ fase & Indeterminada & $\begin{array}{l}\text { Final do I e } \\
1^{\mathrm{a}} \text { met. do II }\end{array}$ & $? ? ?$ \\
\hline 0108 & 1 & $1^{\mathrm{a}}$ fase & D-L 11/14 & $2^{\mathrm{a}}$ met. do I & $2^{\mathrm{a}}$ met. do I \\
\hline 0113 & 1 & $1^{\mathrm{a}}$ fase & D-L 11/14 & $2^{\mathrm{a}}$ met. do I & $2^{\mathrm{a}}$ met. do I \\
\hline 0117 & 1 & $1^{\mathrm{a}}$ fase & D-L 11 & $2^{\mathrm{a}}$ met. do I & $2^{\mathrm{a}}$ met. do I \\
\hline 0121 & 2 & $1^{\mathrm{a}}$ fase & D-L 11/14 & $2^{\mathrm{a}}$ met. do I & $2^{\mathrm{a}}$ met. do I \\
\hline 0147 & 1 & $1^{\text {a }}$ fase ?? & Indeterminada & $2^{\mathrm{a}}$ met. do I & $? ? ?$ \\
\hline
\end{tabular}

Figura 24. Distribuição das lucernas de volutas pelas distintas unidades estratigráficas e fases romanas imperiais detectadas no sector A.

estruturas e estratos associados à fase ocupacional mais antiga de época imperial, que foi datada da etapa flávio-trajana (Viegas e Arruda 2013: 729).

A fase seguinte corresponde, aparentemente, ao momento de maior densidade demográfica no sítio, pelo menos a julgar pela grande renovação e evolução arquitectónica. Atendendo à datação que foi proposta para a anterior, uma cronologia do final do século I e primeira metade do século II d.C. deve ser admissível para a construção e utilização dos edifícios que correspondem à $2^{\mathrm{a}}$ fase, o que está, apesar de tudo, em conformidade com os dados lychnológicos. Todavia, a quase inexistência das lucernas de disco não deixa de surpreender, apesar do número de exemplares do tipo Riotinto/Aljustrel, já claramente do século II. 
Sector C

\begin{tabular}{|c|c|c|c|c|c|}
\hline $\begin{array}{c}\text { Unidade } \\
\text { estratigráfica }\end{array}$ & $\begin{array}{c}\mathrm{N}^{\circ} \mathrm{de} \\
\text { fragmentos }\end{array}$ & Fase & Formas & $\begin{array}{l}\text { Cronologia } \\
\text { da fase }\end{array}$ & $\begin{array}{c}\text { Cronologia } \\
\text { da forma }\end{array}$ \\
\hline 1101 & 3 & & D-L 11/14 & Nível de sup. & $2^{\mathrm{a}}$ met. do I \\
\hline 1140 & 2 & $2^{\mathrm{a}}$ fase & D-L 11/14 & $\begin{array}{l}\text { Final do I e } \\
1^{\text {a }} \text { met. do II }\end{array}$ & $2^{\mathrm{a}}$ met. do I \\
\hline 1141 & 1 & $2^{\mathrm{a}}$ fase & D-L 11/14 & $\begin{array}{l}\text { Final do I e } \\
1^{\text {a }} \text { met. do II }\end{array}$ & $2^{\mathrm{a}}$ met. do I \\
\hline 1163 & 1 & $2^{\mathrm{a}}$ fase & D-L 11/14 & $\begin{array}{l}\text { Final do I e } \\
1^{\text {a }} \text { met. do II }\end{array}$ & $2^{\mathrm{a}}$ met. do I \\
\hline 1168 & 1 & $2^{\mathrm{a}}$ fase & D-L 16 & $\begin{array}{l}\text { Final do I e } \\
1^{\mathrm{a}} \text { met. do II }\end{array}$ & $2^{\mathrm{a}}$ met. do I \\
\hline 1174 & 1 & $2^{\mathrm{a}}$ fase & D-L 9 ?? & $\begin{array}{l}\text { Final do I e } \\
1^{\text {a }} \text { met. do II }\end{array}$ & $1^{\mathrm{a}}$ met. do I \\
\hline 1176 & 2 & $2^{\mathrm{a}}$ fase & $\begin{array}{l}\text { Indet. e Riotinto- } \\
\text { Aljustrel }\end{array}$ & $\begin{array}{l}\text { Final do I e } \\
1^{\text {a }} \text { met. do II }\end{array}$ & séc. II \\
\hline 1179 & 4 & $2^{\mathrm{a}}$ fase & D-L $11 / 14$ e 16 & $\begin{array}{l}\text { Final do I e } \\
1^{\mathrm{a}} \text { met. do II }\end{array}$ & $2^{\mathrm{a}}$ met. do I \\
\hline 1194 & 4 & $2^{\mathrm{a}}$ fase & D-L 11/14 & $\begin{array}{l}\text { Final do I e } \\
1^{\mathrm{a}} \text { met. do II }\end{array}$ & $2^{\mathrm{a}}$ met. do I \\
\hline 1204 & 1 & $2^{\mathrm{a}}$ fase & Indeterminada & $\begin{array}{l}\text { Final do I e } \\
1^{\text {a }} \text { met. do II }\end{array}$ & $? ? ?$ \\
\hline 1210 & 1 & $2^{\mathrm{a}}$ fase & D-L 11/14 & $\begin{array}{l}\text { Final do I e } \\
1^{\mathrm{a}} \text { met. do II }\end{array}$ & $2^{\mathrm{a}}$ met. do I \\
\hline 1216 & 2 & $2^{\mathrm{a}}$ fase & D-L 11/14 & $\begin{array}{l}\text { Final do I e } \\
1^{\text {a }} \text { met. do II }\end{array}$ & $2^{\mathrm{a}}$ met. do I \\
\hline 1226 & 1 & $2^{\mathrm{a}}$ fase & Indeterminada & $\begin{array}{l}\text { Final do I e } \\
1^{\mathrm{a}} \text { met. do II }\end{array}$ & $? ? ?$ \\
\hline 1227 & 1 & $2^{\mathrm{a}}$ fase & D-L 11/14 & $\begin{array}{l}\text { Final do I e } \\
1^{\text {a }} \text { met. do II }\end{array}$ & $2^{\mathrm{a}}$ met. do I \\
\hline
\end{tabular}

Figura 25. Distribuição das lucernas de volutas pelas distintas unidades estratigráficas e na única fase romana imperial detectada no sector $\mathrm{C}$.

Ainda assim, o número reduzido de exemplares da série de disco, até mesmo na última fase ocupacional do sítio, balizada entre os meados e o início do último quartel do século II, tem de ser explicado tendo em consideração o progressivo abandono do sítio, que justificará também a fraca expressão das importações de cerâmica de mesa e de produtos alimentares e até mesmo os modelos construtivos aplicados.

Deste ponto de vista, seria interessante ter uma perspectiva mais clara do consumo lychnológico na margem oposta da ribeira de Bensafrim. Os edifícios destinados ao processamento de peixe detectados sob a actual cidade de Lagos (Ramos et al. 2006; Fabião et al. 2010; Filipe et al. 2010; Gonçalves 2010) pode ter contribuído para o aumento do poder aquisitivo da comunidade humana aí instalada e, naturalmente, para um maior consumo de lucernas da série de disco, quase inexistente em Molião. 


\section{Agradecimentos}

Este trabalho foi realizado no âmbito do Projecto de Investigação "Monte Molião na Antiguidade". À equipa que o integrou: Elisa de Sousa, Pedro Lourenço, Patrícia Bargão e Carlos Oliveira, agradecemos a colaboração neste trabalho, colaboração essa que se consubstanciou quer na escavação propriamente dita, quer nas tarefas realizadas no gabinete, na organização do registo, na inventariação dos materiais, na realização da matriz, na tintagem das plantas e cortes e na própria interpretação da estratigrafia.

À Doutora Elena Móran, agradecemos a disponibilidade sempre manifestada enquanto arqueóloga do município de Lagos para resolver todas as questões relacionadas com o Projecto.

À Uniarq, à FCT e à Câmara de Lagos estamos gratos por terem criado as condições necessárias à concretização deste e de outros trabalhos realizados no contexto do Projecto que desenvolvemos para o sítio.

\section{BIBLIOGRAFIA}

Alarcão, J. (1966): “O espólio da necrópole luso-romana de Valdoca (Aljustrel)". Conimbriga 5: 1-6.

Alarcão, J.; Delgado, M.; Mayet, F.; Alarcão, A. e Ponte, S. (1976): "Céramiques diverses et verres". Fouilles de Conímbriga VI: 93-125.

Amaré Tafalla, $M^{a}$ T. (1989-90): “Lucernas romanas en Hispania (las lucernas romanas de cerámica en la Península Ibérica hasta el siglo IV: introducción y elementos de trabajo)". Anas 2-3: 135-172.

Amaré Tafalla, $\mathrm{M}^{\mathrm{a}} \mathrm{T}$.; Bona López, I. e Borque Ramón, J. (1983): "Avance al estudio de un posible alfar romano de Tarazona: I, las lucernas". Turiaso IV: 93-110.

Amaré Tafalla, Mª T. e García Marcos, V. (1994): "Una producción de lucernas en Asturica Augusta". Zephyrvs XLVII: 273-285.

Andrade, R.; Ferreira, O. e Viana, A. (1957): "Necrópole céltico-romana de Aljustrel”. Separata do Tomo VIII das publicações do XXIII Congresso Luso-Espanhol. Coimbra. Associação Portuguesa para o Progresso das Ciências.

Arruda, A. (2007): Laccobriga. In A ocupação romana na baía de Lagos. Catálogo da Exposição: 7-47. Lagos, Câmara Municipal.

Arruda, A. M. e Pereira, C. (2008): “As ocupações antigas e modernas no Forte de S. Sebastião, Castro Marim”. Xelb 8, I: 365-395. http://www.uniarq.net/ uploads/4/7/1/5/4715235/arruda_pereira_2008.pdf
Arruda, A. e Pereira, C. (2010): "Fusão e produção: actividades metalúrgicas em Monte Molião (Lagos), durante a época romana-republicana". Xelb 10: 695-716. http://www.uniarq.net/ uploads/4/7/1/5/4715235/arruda_pereira_2010.pdf

Arruda, A. e Sousa, E. (2012): “Ânforas republicanas de Monte Molião (Lagos, Algarve, Portugal)". Spal 21: 93-133. http://dx.doi.org/10.12795/spal.2013.i22.05

Arruda, A.; Sousa, E.; Bargão, P. e Lourenço, P. (2008): "Monte Molião (Lagos): resultados de um projecto em curso". Xelb 8, I: 137-168. http://www.uniarq. net/uploads/4/7/1/5/4715235/arruda_et_al_2008.pdf

Arruda, A.; Sousa, E.; Pereira, C. e Lourenço, P. (2011): "Monte Molião: um sítio púnico-gaditano no Algarve (Portugal). Conimbriga L: 5-32.

Arruda, A.; Sousa, E. e Lourenço, P. (2010): “A necrópole romana de Monte Molião (Lagos)". Xelb 10: 267-284.

Arruda, A.; Viegas, C. e Bargão, P. (2010): “A cerâmica comum de produção local do Monte Molião”. Separata de Xelb 10: 285-304.

Arruda, A.; Viegas, C.; Bargão, P. e Pereira, R. (2006): "A importação de preparados de peixe em Castro Marim: da Idade do Ferro à Época Romana". Setúbal Arqueológica 13: 153-176. http://www. uniarq.net/uploads/4/7/1/5/4715235/arruda_et_ al_2006.pdf

Bailey, D. (1980): A Catalogue of the Lamps in the British Museum, II. Roman Lamps made in Italy. Londres, British Museum.

Bailey, D. (1988): A Catalogue of the Lamps in the British Museum, III. Roman Provincial Lamps. Londres, British Museum.

Balil, A. (1965-1966): "Materiales para un índice de marcas de ceramista en lucernas de fabricación hispánica". Pyrenae 1-2: 117-123.

Belchior, C. (1970): "Duas notas sobre lucernas da necrópole romana de Valdoca (Aljustrel)". Conimbriga IX: 75-79.

Bémont, C. e Lahanier, C. (1985): "Lampes tardo-républicaines à Glanum: essai de détermination typologique et physico-chimique”. Revue archéologique de Narbonnaise 18: 221-261.

Berges, G. (1989): Les lamps de Montans (Tam). Une production céramique del Ier. et Ileme. Siècle ap. J.C. Documents d’Archéologie Française 21. Paris. Editions de la maison des Sciences de l'Homme.

Betriu, R. (2008): Les llànties romanes de Baetulo. Tese de Doutorado, Universitat de Barcelona. Inédito.

Bisi, A. (1977): "Le lucerne fittili dei nuovi scavi di Ercolano. L’ Instrumentum domesticum di Erculano 
e Pompei nella prima etá imperiale". Quaderni di Cultura Materiale 1: 73-104.

Bravo García, A. (int.) e Ozaeta Gálvez, Ma . (trad.) (1998): "Plutarco. Vidas Paralelas. AlcibíadesCoriolano, Sertorio-Eumenes". Madrid, Alianza Editorial.

Broneer, O. (1930): Terracotta Lamps. Corinth IV, II, Cambridge. American School of Classical Studies at Athens.

Bussière, J. (2000): Lampes antiques d'Algerie. Monographies Instrumentum 16. Montagnac. M. Mergoil.

Casas i Genover, J. e Soler-Fusté, V. (2006): Lucernas romanas en el extremo nordeste de la Península Ibérica. BAR International Series 1567. Oxford. John and Erica Hedges Ltd.

Campos Carrasco, M.; Pérez Macías, A. e Vidal Teruel, N. (2004): “Alfares y producciones cerámicas en la provincia de Huelva. Balance y perspectivas", en L. Lagóstena Barrios e D. Bernal Casasola, Talleres alfareros y producciones cerámicas en la Bética romana (ss. II a.C. - VII d.C.). B.A.R., International series 1266: 125-160. Oxford. John and Erica Hedges Ltd.

Cerulli, G. (1977): “Officina de lucerne fittili a Pompei. L'Instrumentum domesticum di Ercolano e Pompei nella prima etá imperiale". Quaderni di Cultura Materiale 1: 53-67.

Del Amo, M. (1976): Restos materiales de la población romana de Onuba. Huelva Arqueológica II. Huelva. Diputación Provincial.

Delgado Domínguez, A. e Pérez Macías, A. (2014): "Artífices y industrias auxiliares en las minas Hispanicas", en M. Bustamante Álvarez e D. Bernal Casasola (eds.), Artífices idóneos. Artesanos, talleres y manufacturas en Hispania: 389-419. Mérida. Consejo Superior de Investigaciones Científicas.

Deneauve, J. (1969): Lampes de Carthage. Paris, Éditions du Centre national de la recherche scientifique.

Detry, C. e Arruda, A. (2013): "A fauna da Idade do Ferro e Época romana de Monte Molião (Lagos, Algarve): continuidades e rupturas na dieta alimentar". Revista Portuguesa de Arqueologia 15: 215-227. http://repositorio.ul.pt/handle/10451/10894

Dias, V. (2010): A cerâmica campaniense do Monte Molião, Lagos. Dissertação de Mestrado em Arqueologia, Universidade de Lisboa. Inédito.

Díaz Trujillo, O. (1988): "Las lucernas de la Casa de los Estucos (Complutum, Alcalá de Henares)", en I Encuentro de Historiadores del Valle del Henares: 187-196. Guadalajara. Institución de Estudios Complutenses.
Dressel, E. (1899): "Lucernae formae", en CIL XV, Vol. II: 1

Fabião, C. (1998): O Mundo Indígena e a sua Romanização na área céltica do território hoje português. Tese de Doutorado, Universidade de Lisboa. Inédito.

Fabião, C. (2007): “Estácio da Veiga e a exploração de recursos marinhos no Algarve, em época romana". Xelb 7: 131-142. http://repositorio.ul.pt/ bitstream/10451/10168/1/estacioveigacetariae.pdf

Fabião, C. (2009): "Las ánforas de Lusitania", en D. Bernal Casasola e A. Ribera i Lacomba (eds.), Cerámicas hispanorromanas. Un estado de la cuestión. XXVI Congreso Internacional de la Asociación Rei Cretariae Romanae Fautores: 725-745. Cádiz. Servicio de Publicaciones de la Universidad.

Fabião, C.; Filipe, I. e Brazuna, S. (2010): "Produção de ânforas em época romana em Lagos: os dados resultantes das intervenções de contrato realizadas no âmbito do Projecto URBCOM". Xelb 10: 323-336. http://repositorio.ul.pt/handle/10451/9773

Fernández Chicarro, C. (1954): "Museo Arqueológico de Sevilla". Memorias de los Museos Arqueológicos Provinciales XV: 61-124. Madrid. Ministerio de Educación Nacional.

Fernández Gómez, F. e Hurtado Rodríguez, L. (1991): "Lucernas romanas del Bajo Guadalquivir". Revista de Arqueología 126: 32-43.

Filipe, I.; Brazuna, S. e Fabião, C. (2010): “Ocupação Romana da Área Urbana de Lagos: Novos Dados Resultantes do Projecto URBCOM". Xelb 10: 305-322.

Fischbach, O. (1896): Römischen Lampen aus Poetovio. Mitteillungen des historischen Vereines für Steirmark XLIV. Graz. Selbstverl. Verfasser.

Gambelas, R. (2009): As Anforas do Centro Oleiro Romano do Martinhal (Vila do Bispo - Algarve). Dissertação de Mestrado, Universidade do Algarve. Inédito.

Gamito, T. J. (1992): “Cemitério romano do século II/III - Faro, Rua das Alcaçarias”. Cominbriga 31: 99-118.

García Giménez, R.; Morillo Cerdán, A. e Bernal Casasola, D. (1999): “Consideraciones sobre los centros productores de lucernas tipo Andújar: análisis arqueométrico de materiales procedentes de los Villares de Andújar (Jaén) y de la submeseta Norte", en J. Capel Martínez (coord.), Arqueometría y arqueología: 187-195. Granada.

García Vargas, E. (2006): "Pesca y salazones en la Bética altoimperial", en I Conferencia Internacional Historia de la pesca en el ámbito del Estrecho, Vol. II: 531-576. Sevilha. 
Gomes, J. A. (2010): Estuário da Ribeira de Bensafrim. Leitura geo-arqueossismológica. Dissertação de Mestrado, Universidade de Lisboa. Inédito.

Gonçalves, C. (2010): “A industria de preparados piscícolas na Baía de Lagos durante a Época Romana". Xelb 10: 337-349. http://www.uniarq. net/uploads/4/7/1/5/4715235/filipe_brazuna_fabio_2010.pdf

Grimal, P. (1999): Dicionário da mitología Grega e Romana. Lisboa, Difel ( $3^{\text {a }}$ Edição).

Joly, E. (1974): Lucerne del Museo di Sabratha. Monografie di Archeologia Libica 11. Roma. L'erma di Bretschneider.

Lamboglia, N. e Beltrán, A. (1952): “Apuntes sobre cronología cerámica”. Caesaraugusta 3: 87- 89.

Loeschcke, S. (1919): Lampen aus Vindonissa, Ein Beitrag zur Geschichte von Vindonissa und des Antiken Beleuchtungwesens. Zurich, In Kommission bei Beer \& Cie.

López Rodríguez, J. (1981): “La colección de lucernas de la casa de la Condesa de Lebrija (Sevilla)". Boletín del Seminario de Estudios de Arte y Arqueología 47: 95-140.

Lourenço, P. (2010): A pesca, na antiguidade- O caso de Monte Molião, Lagos. Dissertação de Mestrado, Universidade de Lisboa. Inédito.

Luzón Nogué, J. (1967): "Lucernas mineras de Riotinto". Archivo Español de Arqueología 40: 138-150.

Maia, M. e Maia, M. (1997): Lucernas de Santa Bárbara. Castro Verde, Cortiçol.

Modrzewska, I. (1992): "Le lucerne "da miniera" nel Museo Archeologico di Barcelona". Rivista de Archeologia XVI: 65-67.

Morais, R. (2005): Autarcia e comércio em Bracara Augusta: contributo para o estudo económico da cidade no período Alto-Imperial. Braga, Unidade de Arqueologia da Universidade do Minho.

Morais, R. (2010): "Lucernas", en J. Alarcão; P. Carvalho e A. Gonçalves (eds), Castelo da Lousa Intervenções Arqueológicas de 1997 a 2002. Studia Lusitana: 173-180. Mérida. Museo Nacional de Arte Romano.

Moreno Jiménez, F. (1991): Lucernas romanas de la Bética. Madrid, Universidad Complutense.

Morillo Cerdán, A. (1999): Lucernas romanas en la región septentrional de la Península Ibérica. Monographies Instrumentum 8/2. Montagnac, M. Mergoil.

Morillo Cerdán, A. (2008): "Producciones cerámicas militares en Hispania”, en D. Bernal Casasola e A. Ribera i Lacomba (eds.), Cerámicas hispanorromanas. Un estado de la cuestión. XXVI Congreso
Internacional de la Asociación Rei Cretariae Romanae Fautores: 275-296. Cádiz. Servicio de Publicaciones de la Universidad..

Morillo Cerdán, A. e Rodríguez Martín, G. (2008): "Lucernas hispanorromanas", en D. Bernal Casasola e A. Ribera i Lacomba (eds.), Cerámicas hispanorromanas. Un estado de la cuestión. XXVI Congreso Internacional de la Asociación Rei Cretariae Romanae Fautores: 291-312. Cádiz. Servicio de Publicaciones de la Universidad..

Nunes, J.; Fabião, C. e Guerra, A. (1990): “As lucernas do acampamento militar romano da Lomba do Canho (Arganil)". Conimbriga XXIX: 69-90.

Pavolini, C. (1977): "Le lucerne fittili romane del Museu Nacionale di Napoli. L'Instrumentum domesticum di Ercolano e Pompei nella prima etá imperiale". Quaderni di Cultura Materiale 1: 68-72.

Pavolini, C. (1987): "Le lucerne romane fra il III sec. a.C. e il III sec. d.C.", en P. Lévêque e J.-P. Morel (eds.), Céramiques Hellénistiques et Romaines II: 139-189. Paris.

Pereira, C. (2008): As Lucernas romanas de Scallabis. Dissertação de Mestrado, Universidade de Lisboa. Inédito.

Pereira, C. (2012a): "As Lucernas romanas de Ossonoba. Um conjunto ambíguo”. Habis 43: 119-147.

Pereira, C. (2012b): "O sítio romano do Vidigal, Aljezur". Revista Portuguesa de Arqueologia 15: 155 179. http://hdl.handle.net/10451/10178

Pereira, C. (2013): "Lucernas romanas de Alcácer do Sal. Entre a prática e o sagrado". Al-Madan 17, Tomo 2, Adenda electrónica: 13-28. http://hdl. handle.net/10451/10877

Pereira, C. (2014a): Roman lamps of Scallabis (Santarém, Portugal). B.A.R. International Series 2627. Oxford.

Pereira, C. (2014b): As necrópoles romanas do Algarve. Acerca dos espaços da morte no Extremo Sul da Lusitânia. Tese de Doutorado, Universidade de Lisboa. Inédito.

Pereira, C. (2014c): "Reflexiones sobre el decaer del comercio de lucernas romanas en el Occidente peninsular". Onoba, Revista de Arqueología y Antigüedad 2: 191-206.

Pereira, C. e Albuquerque, P. (2014): “A diacronia da aventura de Ulisses com o Ciclope no repertório iconográfico "lychnológico". Habis 45: 7-28.

Pérez Macías, A. e Delgado Domínguez, A. (2012): Las cupae de Riotinto (Huelva). Los Bañales, Series Monografias.

Raddatz, K. (1973): Mulva I. Madrider Beitrage 2. Mainz. 
Ramos, C.; Almeida, R. e Laço, T. (2006): “O Complexo Industrial da Rua Silva Lopes (Lagos). Uma primeira leitura do sítio e análise das suas problemáticas no quadro da indústria conserveira da Lusitânia meridional", en Simpósio Internacional "Produção e comércio de Preparados Piscícolas durante a Proto-História e a Época Romana no Ocidente da Península Ibérica - Homenagem a Françoise Mayet. Setúbal Arqueológica 13: 83100. Setúbal.

Ricci, M. (1973): "Per una cronologia delle lucerne tardo-repubblicane”. Rivista di Studi Liguri II-IV: 168-234.

Ricci, A. (2002): "Le lucerne dei relitti sottomarini". Revista di Studi Liguri LXVII-LXVIII (20012002): 305-420.

Rodríguez Martín, F. (2002): Lucernas romanas del Museo Nacional de Arte Romano (Mérida). Monografías Emeritenses 7. Mérida, Museo Nacional de Arte Romano.

Romero Carnicero, Mª V. (1990): "Las lucernas republicanas de Numancia y sus campamentos". Boletín del Seminario de Estudios de Arte y de Arqueología LVI: 257-296.

Sáez Romero, A. (2005): “Aproximación a la tipología de la cerámica comun púnico-gadirita de los ss. III - II a.C." Spal 14: 145-177. http://dx.doi. org/10.12795/spal.2005.i14.06

Sáez Romero, A. (2008): La producción cerámica en Gadir en época tardopúnica (siglos -III/-I). Torre Alta: Balance de la investigación y novedades histórico-arqueológicas. B.A.R. International Series 1812. Oxford.

Sáez Romero, A. (2014): Alfares y saladeros de Gadir. Una aproximación arqueológica a la economía conservera de la Bahía de Cádiz en época púnica y tardopúnica (siglos-VIa-I). Tese de Doutorado, Universidad de Cádiz. https:/www.academia.edu/8519425/ Alfares_y_saladeros_de_Gadir._Una aproximaci $\% \mathrm{C} 3 \% \mathrm{~B} 3 \mathrm{n}$ arqueol $\% \mathrm{C} 3 \% \mathrm{~B} 3$ gica_a la econom $\%$ C $3 \% \overline{\mathrm{A}} \mathrm{da}$ conservera $\overline{\mathrm{de}}$ la_Bah\%C3\%Ada_de_C\%C3\%A 1 diz en_ $\%$ C $3 \%$ A 9 poca_p $\%$ C $3 \%$ Banica_y tardop $\%$ C3\%Banica_siglos_-VI_a_-I_.

Santos, M. ${ }^{\mathrm{a}}$ L. (1971): Arqueologia Romana do Algarve. Vol. I. Lisboa, Associação dos Arqueólogos Portugueses.
Santos, M. ${ }^{\mathrm{a}}$ L. (1972): Arqueologia Romana do Algarve. Vol. II. Lisboa, Associação dos Arqueólogos Portugueses.

Silva, P.; Borja, F.; Zazo, C.; Goy, J.; Bardají, T.; De Luque, L.; Lario, J. e Dabrio, C. (2005): “Archaeoseismic record at the ancient Roman city of Baelo Claudia (Cádiz, south Spain)". Tectonophysics 408: 129-146. doi:10.1016/j.tecto.2005.05.031

Sotomayor Muro, M.; Pérez Casas, A. e Roca Roumens, M. (1976): "Los alfares romanos de Andújar (Jaén): Dos nuevas campañas". Noticiario Arqueológico Hispánico 4: 111-147.

Sousa, E. (2009): A cerâmica de tipo Kuass no Algarve. Lisboa, UNIARQ.

Sousa, E. (2010): "The use of "Kouass ware" during the republican period in Algarve (Portugal)". Rei Cretariae Romanae Fautorum Acta 41: 523-528.

Sousa, E. e Arruda, A. M. (2010): “A gaditanização do Algarve”. Mainake 32 (II): 951-974.

Stienstra, P. (1986): "Technological Research on Composition and Texture of Ancient Pottery - a note of sense and nonsense". Newsletter III: 10-47.

Ulbert, T. (1984): Cáceres el Viejo: ein spätrepublikanisches Legionslager in Spanisch-Extremadura. Deutsches Archäologisches Institut Madrid. Mainz, Zabern.

Vázquez Paz, J. (2012): "Producción de lucernas altoimperiales en Hispalis: el taller de la Plaza de la Encarnación de Sevilla”, en D. Bernal Casasola e A. Ribera i Lacomba (eds.), Cerámicas hispanorromanas II. Producciones regionales: 309-323. Cádiz, Universidad de Cádiz.

Viana, A. e Nunes, F. (1956): "Lucernas de Peroguarda. Notas Históricas, Arqueológicas e Etnográficas do Baixo Alentejo". Arquivo de Beja XVI: 123-138.

Viegas, C. (2006): “A ocupação romana de Castro Marim". Xelb 6, I: 241-260.

Viegas, C. (2007): “Amphorae imports in southern Lusitania (Algarve): recent evidence from urban sites. The roman town of Balsa". Rei Cretarice Romance Fautorum 40: 493-504.

Viegas, C. (2011): A ocupação romana do Algarve. Estudo do povoamento e economia do Algarve central e oriental no período romano. Lisboa, UNIARQ.

Viegas, C. e Arruda, A. (2013): Ânforas romanas de época imperial de Monte Molião (Lagos): as Dressel 20". Arqueologia em Portugal, 150 anos: 727-735. Lisboa, Associação dos Arqueólogos Portugueses. 